\title{
Day-of-the-Week (DOW) and Intraday Effects on Stock Returns: Evidence from the Selected Countries covering the Asia-Pacific Rim
}

\author{
Papia Mitra ${ }^{1}$ \\ ${ }^{1}$ Assistant Professor, Department of Commerce, J.D. Birla Institute, Kolkata, India
}

\begin{abstract}
The paper tries to analyze the conditional and unconditional market risk factors to examine the day of the week and intraday effects on stock returns of some selected countries covering the Asia-Pacific Rim. The paper takes into account six stock indices, namely, Hang Seng, Jakarta Composite Index, Kualalampur FTSE Bursa, Strait Times Index, TSEC Weighted Index and NSE Nifty. In order to fulfill the objectives of the paper, five models are estimated. In each model risk factors are allowed to vary. The study covers the period from 0204-2001 to 31-03-2015. However, the results suggest that for most of the indices, Monday suffers from maximum volatility. However, for all the indices, there exists significant day of the week effect at least in one of the five estimated models. Moreover, for most of the indices, the market risk factor is statistically significant in explaining variation in the intraday as well as interday stock returns.

Keywords: Day-of-the-Week Effect, Intraday \& Interday Returns, Asia-Pacific Rim, Unit Root Test, Market Risk Factor.
\end{abstract}

\subsection{Day-of-the-Week (DOW) Effect}

\section{INTRODUCTION}

It is also called Calendar Effect. It includes many effects that deal with the time. The stock returns depend on the days of the week. This implies that the stock returns vary across the days of the week. There is a tendency of the stock indices to exhibit negative and minimum return on Monday and a maximum return on Friday. However, Monday gives minimum return on an average and maximum volatility on diverse range of securities, commodities and equities. Previous studies, since 1920, do not adequately explain the exact implication of the day-of-the-week effect. Since, mid 1970s and mid 1980s, large firm securities had exhibited reverse weekend effect, in which the difference between the Monday return and the returns on other days of the week is not statistically significant.

The calendar effects (DOW effect, January effect, Holiday effect) in stock market returns are widely studied and documented in finance literature [Berument and Kiymaz, 2001; Berument and Kiymaz, 2003; Apolinario R.M.S et. al., 2006; Smirlock M et.al., 1986; Yalcin and Yucel, 2006; Aksoy M et. al. 2012; Basher and Sadorsky, 2006; Tevdovski D et. al, 2012] . It is based on the assumption that the past behavior of a stock's price is rich in information pertaining to its future behavior. Since the pattern of the past behavior will tend to recur in future, hence, it is useful to understand these patterns in order to predict the future behavior of prices.

For any rationale financial decision-maker, returns constitute only one part of the decision-making process. However, the other part is the risk or volatility of returns. Hence, it is important to know whether there are variations in the volatility of the stock market returns over the days of the week. Moreover, it is important to know whether a high (low) return is associated with correspondingly high (low) volatility for a given day. Whether the volatility level of stock price is related with the volatility level of a given day is quite important to know for the investors. If the investors can identify a certain pattern in volatility, then it would be easier to make investment decisions based on both returns and risk. The investors who dislike risk may adjust their portfolios by reducing their investments in those assets whose volatility is expected to rise [Berument \& Kiymaz, 2001; Berument \& Kiymaz, 2003; Aksoy M et. al. 2012].

However, Basher and Sadorsky (2006) investigated the DOW effect on nineteen emerging markets covering the period from December 31, 1992 and October 31, 2003 taking into account the market risk factors provided by the excess returns of the MSCI world stock market index. However, it is defined in different ways in five different regression models. Moreover, it is also allowed to vary across the days of the week. However, the empirical results claim absence of DOW effect in most of the concerned stock markets even after adjusting the market risk factors. However, different models give us different results but the overall day of the week effect is present in Philippines, Pakistan and Taiwan even after adjusting for the market risk. Hence, some emerging stock markets do exhibit strong day-of-the-week effects even after accounting for conditional market risk factor.

The investment opportunities in the international markets depend on the degree of integration or segmentation of the said markets. If markets are highly integrated than opportunities of receiving profits from an international 
portfolio are not so high. The presence of anomalies in international financial markets can be a clear sign that a lack of integration among these markets exists, thus investment opportunities derived from different behaviors in the generation of returns are available [Apolinario R.M.S et. al., 2006].The investors adjust their portfolios by reducing their investments in assets whose volatility is expected to increase. Uncovering certain volatility patterns in returns might also benefit investors in valuation, portfolio optimization, option pricing and risk management (Berument \& Kiymaz, 2003). One of the explanations of DOW effect is that Monday is the day with the lowest trading volume and hence, the propensity of the individuals to transact on Monday is the highest relative to other days of the week and also the propensity of individuals to sell on Monday is higher than their propensity to buy.The longer the maturity period of the bonds, lower will be the return on Monday. However, the Measurement Error has been considered as one of the reasons behind the DOW effect. This phenomenon is prominent in the firms with low market capitalization. The measurement error occurs when a particular stock has low merchantability. This error leads to positive effect on Friday's return and negative effect on Monday's return which implies that there must prevail a negative correlation between Monday and Friday returns. But, the correlation between the two is not only negative but also the highest in the week.

Interday stock returns are calculated from the closing prices. The closing price is the price according to which the last transaction takes place. Hence, they do not reflect the real price at which the order of the sales and purchase are balanced, rather, it is an unreal price that presents high variations. Hence, the DOW effect occurs due to high supply (due to high ask prices) on Mondays and by high demand (due to low bid prices) on Fridays. However, various past researches reject this explanation of DOW effect.

Another explanation to the DOW effect is the Trading Activity of the Investors. This is the most satisfactory explanation of the DOW effect. This explanation is based on the Information Processing Hypothesis. The hypothesis says that, the investors, throughout the week cannot get plenty of time to search for the information. Hence, they have to depend on stockbrokers' suggestions. However, the stockbrokers' suggestions tend to keep moving with the market's promptitude.

Investor's Psychology also plays an important role in explaining the DOW effect. Monday has been considered as the worst day as it is the first working day of the week. The investors behave in pessimistic way on Mondays. This leads to sales on this day and thereby, a price falls. On the other hand, Friday is considered as the best day as it is the last working day of the week. The investors behave optimistically on this day. This leads to purchases and thereby, a price rise [Lyroudi K., et al., 2002].

Certain studies also included the calendar anomalies in the foreign exchange and T-bill markets as well. Rogalski (1984), Kiymaz and Berument (2001 \& 2003) and Yalcin and Yucel (2006) concluded in their respective research papers that the stock returns and volatility differ for each day of the week. However, Basher and Sadorsky (2006) investigated the day of the week (DOW) effect on nineteen emerging markets taking into account the market risk factors where it is defined in different ways in five different regression models. However, the empirical results claim absence of DOW effect in most of the concerned stock markets even after adjusting the risk factors. However, most of the studies of the European stock markets claim for the inexistence of the DOW effect on the stock market return on most of the stock indexes, though the existence of abnormal volatility in the equation of conditional variance was observed [Apolinario et. al; 2006]. Moreover, the Athens Stock Exchange exhibits the DOW effect in both return and volatility covering the period 1995-2003 [Kenourgios et. al., 2005]. Moreover, Tevdovski D. et. al. (2012) in their paper examined the day of the week effect considering five countries of South-Eastern Europe (Bosnia and Herzegovina, Bulgaria, Croatia, Macedonia and Serbia) covering the period 2006 to 2011. However, this paper also claims for the absence of DOW effect on all concerned stock markets during the period of analysis. However, some other European countries like Portugal, Italy, Greece, Spain and Ireland exhibit the DOW effect even in the financial crisis period. Hence, it is of the notion that the result of a special type of institutional arrangement in these countries [Aksoy et. al., 2012].

However, the selected countries covering the Asia-Pacific rim (Taiwan, Singapore, Hong Kong) exhibit significant DOW effect characterized by negative Monday and positive Friday effects. Moreover, adjustment of the equity market risk factor changes the empirical result with DOW effect persisting only in Taiwan [Chia et al; 2008]. The Karachi Stock Exchange (Pakistan) exhibited significant Tuesday Effect on stock returns in the period January 2006 to December 2010 [Hussain et.al., 2011].However, Botswana, Egypt, Ghana, Nigeria and South Africa are examined for the existence of DOW effect. The results confirm the existence of DOW effect on stock returns of all the concerned countries. Botswana and Nigeria recorded the maximum and minimum returns respectively. Moreover, these stock markets have accounted a tendency of high volatility [Chukwogor, 2007].

Michael Smirlock \& Laura Starks (1986) in their paper examined the day of the week effect considering the hourly values of the Dow Jones Industrial Average. The analysis covered the period starting from 1963 to 1983. However, the entire period was divided into two sub-period, 1968-1974 and 1974-1983. It was found that in the $1^{\text {st }}$ sub-period, negative returns characterized each hour of trading on Monday, while the $2^{\text {nd }}$ sub-period was characterized by a positive returns on Monday. 
Aslı Bayara and Özgür Berk Kanb (2002) in their paper performed the day of the week effect considering stock indices of nineteen countries over the world. The daily market interday returns are calculated for all the indices in terms of local currency as well US dollars. A daily pattern in stock markets has been observed for fourteen countries in local currency returns and for twelve countries in dollar returns. However, each country exhibits different effects.

\subsection{Market Risk Factor in Stock Markets}

Any rational investor before investing in the stock market must decide how much risk it is willing to take and what the expected potential reward out of the investment is. Market risk is the danger of the market fall due to variety of reasons like struggling economy, concern over sagging profits and so on. Here, the paper is concerned about the equity risk that is defined by the risk that the price of the stock index and/or their implied volatility will change.

Sometimes a particular stock becomes less attractive to the investors possibly because of the emergence of the hot sector which is attracting buyers. It is also poor management and poor decisions such as diversifying into unfamiliar products or markets, failing to make needed changes such as automation, marketing and key strategies that affect the investment decision of the investors. Various macroeconomic variables affect the stock prices. An economic recession which is characterized by high rate of unemployment, low inflation rate and low aggregate demand may lead to trouble for the stock market. Whenever, the aggregate demand in the economy falls down, the producers reduce their production which leads to less earning lowering the investment in the stock market. It is more painful for the investor to be not aware of the period when the economy will out of this financial crisis. This uncertainty makes the companies cautious about expanding and hiring, which makes unemployment worse.

Many companies across the world especially the ones with larger capital have expanded their business overseas. This global diversification is a boon when the business is slow domestically. When the global markets struggle it spills into the domestic market. The economic problems faced by the foreign economies of the world have direct bearing on the stock prices of the domestic stock market.

Generally, the companies announce the bad news on Fridays, i.e. in the weekend in order to allow the market to absorb the shock during the two days that intermediate till the opening of the market on Monday. On the other hand, good news is announced immediately.

\subsection{Stock Markets Covering the Asia-Pacific Rim}

In western stock markets, the institutional investors such as mutual funds, pension funds and insurance companies predominate. A company's management owns some of the shares, but the total management holding is usually insufficient to exercise control. The performance of the management is very crucial as this requires majority of the shareholders to support their policies.In Taiwan, Hong Kong and various other south-east Asian countries, the companies are generally controlled by the family groups who themselves hold high positions in the companies. Such companies are owner-managed. Hence, the management decisions can be taken in a flexible manner without any fear of any takeover. These companies lack in formal planning process and may make shortterm speculative forays on the management's whim. This results to the asymmetric information problems faced by the investors which is more than that in the western economies whose company's performance is comparatively more transparent. This leads to risk of investing in such markets. As the companies are ownermanaged, hence, the desire to pass on companies to future generation motivates them to opt for long run goals.

All countries considered in the study except Jakarta and Hong Kong, enjoyed high growth rates during the early and mid 1990s. Hong Kong's low growth rate in the 1990s was due to the capacity constraints [Montagu-Pollack et. al.; 1992].The trading in Hong Kong stocks started on an informal basis in 1866. An association of stockbrokers in 1891 established a formal stock exchange. The second stock exchange was established in 1921. The second stock exchange emerged with the first to form the Hong Kong stock exchange in 1947. Till 1974, there was absence of any regulatory body. In 1974, the securities ordinance was enacted and the office of commissioner for securities was established. The Singapore Stockbrokers' Association was formed in 1930 . Trading was conducted on a more formal basis. In 1938, the stockbrokers from the peninsula were admitted, and the body was renamed as the Malaysian Stockbrokers' Association. In 1960, these stockbrokers' were united to form the Malaysian Stock Exchange. Kualalampur was the trading room. The development of banking and financial services is a major economic strategy of Singapore since 1970s. Singapore is a relatively small economy and has been benefitted from the drastic economic growth in the recent years. The dealing system is fully computerised. However, the government's privatisation polices have encouraged the residents of the country to have more of a direct stake in the growth and prosperity of the economy.

In the 1950s, in Taiwan, there was no such existence of formal stock market. The first initiation was made when Taiwan Stock Exchange (TSE) was formed one year after the formation of the Securities and Exchange Commission on Sep 01, 1960. TSE is the only exchange for trading securities in Taiwan. By October 1988, TSE 
became the third largest capital market in the world in terms of total capitalisation. The foreign firms and individuals were not allowed to invest in its stocks and bonds before December 1983. On January 1991, the market became more liberal to the foreign investors although, strict government controls on levels of foreign investment was there. However, over the past decade, Taiex remains a relatively famous investment destination in Taiwan.

The National Stock Exchange (NSE) played an important role in reforming the Indian Securities Market. NSE was started with an intension of bringing transparency to Indian market by a clutch of some leading Indian financial institutions. It can be termed as India's largest exchange, globally in currency trading, index options and cash market trade. The exchange was included in 1992 as a tax-paying company and was renowned as a stock exchange in 1993 under the Securities Contracts (Regulation) Act, 1956. NSE has a market capitalization of more than US $\$ 0.989$ trillion and 1,635 companies listed as of July 2013.The transparency, efficiency and low transaction prices that were offered by NSE significantly increased the attractiveness of the Indian Stock Market to the domestic and international investors.

\section{OBJECTIVES OF THE PAPER}

The present paper examines the day-of-the-week effect in six stock markets covering the Asia-Pacific rim and extends the existing literature by including unconditional and conditional risk factors in the analysis. In addition, risk is allowed to vary across the days of the week. This study also differs from previous research by examining excess market returns in US dollars which is more relevant from the perspective of an international investor.

However, in order to fulfil the objectives, the analysis is planned in the following way:-

- The descriptive statistic properties for the days of the week, i.e., to check for the normality of the returns (intraday and interday) for all the 6 stock indices.

- The stationarity of the returns (intraday and interday) using unit root test.

- The DOW effect on the stock market returns (intraday and interday) with no market risk factor.

- The DOW effect on the stock market returns (intraday and interday) incorporating a constant market risk factor.

- The DOW effect on the stock market returns (intraday and interday) incorporating a daily market risk factor.

- The DOW effect on the stock market returns (intraday and interday) incorporating conditional market risk factor.

- The DOW effect on the stock market returns (intraday and interday) incorporating conditional daily market risk factor.

\section{DATA SOURCE AND RESEARCH METHODOLOGY}

The paper considers 6 stock markets from the countries covering the Asia-Pacific rim which are as follows:Hang Seng Index (Hong Kong), Jakarta Composite Index (Jakarta), Kualalampur FTSE Bursa (Malaysia), Strait Times Index (Singapore), TSEC Weighted Index (Taiwan) and NSE Nifty (India).

The paper covers the period between April 2, 2001 and March 31, 2015. This is because it tries to analyze the presence of day of the week effect on the aforesaid stock indices in the last fourteen years of the ongoing century. All the data are in US dollars so that the investment decisions are from the perspective of an US investor or an international investor who has US dollar trading account.

The data are collected from Yahoo India and www.google.com/finance.

The data is converted in order to obtain the daily returns (intra-day and inter-day returns) defined as:

$\mathrm{R}_{\mathrm{t}}=\log \left(\right.$ Closing price $_{\mathrm{t}} /$ Opening price $\left.\mathrm{t}\right) \times 100$

where $R_{t}$ is the intra-day return for the $t$-th day.

$\mathrm{V}_{\mathrm{t}}=\log ($ Closing price $/$ Closing price $\mathrm{t}-1) \times 100$

where $\quad V_{t}$ is the inter-day return for the t-th day.

The present study tries to find out the Descriptive Statistics of returns of the concerned stock indices/prices considering the overall period (2000 to 2015). The parameters such as mean return (in percentage), standard deviation (risk in percentage), skewness (asymmetry), kurtosis (peakedness), Jarque-Bera test of normality are applied to find out the stochastic properties of the data series. The last three parameters are used in order to find out the presence of normality in the frequency distribution.

Further, a stationary time series is one whose statistical properties like mean, variance and autocorrelation are time-invariant, i.e. the statistical properties will be the same in future as they have been in the past. These statistical descriptors are useful to determine the future behavior of any data series provided the series is stationary. Hence, non-stationary time series data give certain misleading results. To avoid such problem of non-stationarity in data series, we first subject the data to stationarity test by using Augmented Dickey Fuller (ADF) test.

The models in which ADF test are applied is as follows:- 
$\Delta R_{t}=\alpha+\beta t+\mu_{1} R_{t-1}+\delta_{1} \Delta R_{t-1}+\ldots \ldots . .+\delta_{p-1} \Delta R_{t-p+1}+\epsilon_{1+\ldots \ldots .(1)}$

$\Delta V_{t}=\alpha+\beta t+\mu_{2} V_{t-1}+\delta_{1} \Delta V_{t-1}+\ldots \ldots . .+\delta_{p-1} \Delta V_{t-p+1}+\epsilon_{2 t \ldots \ldots \ldots} \ldots$ (2)

$\alpha$ is a constant, $\beta$ is the coefficient of the trend term $(\mathrm{t})$ and $\mathrm{p}$ is the lag order of the autoregressive process. The

following null hypothesis is tested:-

$\mathrm{H}_{0}$ : non-stationarity (presence of unit root) against

$\mathrm{H}_{1}$ : stationarity (absence of unit root)

In order to find test the above hypothesis, a computed ADF t-statistic has been formulated. If the absolute value of the computed ADF test statistic turns out to be greater than that of its critical value at $5 \%$ level of significance, null hypothesis is rejected. If the original series turns out to be non-stationary then we again go for unit root test at first difference. This process will continue until and unless the series turns out to be stationary. This test is applied for the returns (Intraday \& Interday) of all the selected stock indices.

1.4. Model Specification: Five models are estimated.
3.1.1. Model I: $\mathrm{R}_{\mathrm{it}}=\sum \beta_{\mathrm{ij}}{ }^{1} \mathrm{D}_{\mathrm{jt}}+€_{3 \mathrm{it}}$
\[ \mathrm{V}_{\mathrm{it}}=\sum \beta_{\mathrm{ij}}{ }^{2} \mathrm{D}_{\mathrm{jt}}+€ \]
$\mathrm{V}_{\mathrm{it}}=\sum \beta_{\mathrm{ij}}{ }^{2} \mathrm{D}_{\mathrm{jt}}+€_{4 \mathrm{it}} \ldots \ldots \ldots(4)$
$\mathrm{i}=1, \ldots ., 6 ; \mathrm{j}=1, \ldots ., 5$

It is the simplest model. $D_{1}, \ldots ., D_{5}$ are the day of the week $(0,1)$ dummy variables for the five days of the week on which the return is observed that are incorporated to quantify the qualitative variables (days of the week). However, this model does not include any such risk factor. The daily returns may be higher (lower) on different days of the week because of higher (lower) risks involved.

$$
\begin{aligned}
\text { 3.1.2. Model II: } R_{\mathrm{it}}=\sum \beta_{\mathrm{ij}}{ }^{1} \mathrm{D}_{\mathrm{jt}}+\lambda_{\mathrm{i}}{ }^{1} \mathrm{MR}_{\mathrm{t}}+€_{5 \mathrm{it}} \ldots \ldots .(5) & \mathrm{i}=1, \ldots, 6 ; \mathrm{j}=1, \ldots ., 5 .
\end{aligned}
$$

Where MR is the market risk factor provided by the excess returns on the global index (SPDR Global Dow ETF). In this model, the risk factor is constant across the week.

$$
\begin{aligned}
\text { 3.1.3. Model III: } \mathrm{R}_{\mathrm{it}}=\sum \beta_{\mathrm{ij}}{ }^{1} \mathrm{D}_{\mathrm{jt}}+\sum \gamma_{\mathrm{ij}}{ }^{1}\left(\mathrm{D}_{\mathrm{jt}} \mathrm{MR}_{\mathrm{t}}\right)+€_{7 \mathrm{ti}} \ldots \ldots \ldots .(7) \\
\mathrm{V}_{\mathrm{it}}=\sum \beta_{\mathrm{ij}}{ }^{2} \mathrm{D}_{\mathrm{jt}}+\sum \gamma_{\mathrm{ij}}{ }^{2}\left(\mathrm{D}_{\mathrm{jt}} \mathrm{MR}_{\mathrm{t}}\right)+€_{8 \mathrm{it}} \ldots \ldots \ldots .(8)
\end{aligned}
$$$$
\mathrm{i}=1, \ldots ., 6 ; \mathrm{j}=1, \ldots ., 5 \text {. }
$$

All the above 3 models include unconditional risk factors. Model II can be improved by adding slope interaction dummy variables that allow risk to vary across the days of the week.

The next two models are the conditional models that include the conditional market risk factors. Model IV is similar to model II. The only difference is that model IV includes a conditional variable that depends upon whether the market risk is positive or negative. On the other hand, model V includes slope dummy variables that include the market risk as well as the days of the week variables.

$$
\begin{aligned}
& \text { 3.1.4. Model IV: } \mathrm{R}_{\mathrm{it}}=\sum \beta_{\mathrm{ij}}{ }^{1} \mathrm{D}_{\mathrm{it}}+\gamma_{\mathrm{iu}}{ }^{1}\left(\mathrm{D}_{\mathrm{ut}} \mathrm{MR}_{\mathrm{t}}\right)+\gamma_{\mathrm{id}}{ }^{1}\left(\mathrm{D}_{\mathrm{dt}} \mathrm{MR}_{\mathrm{t}}\right)+€_{9 \mathrm{it}} \ldots \ldots \text { (9) } \\
& \mathrm{V}_{\mathrm{it}}=\sum \beta_{\mathrm{ij}}{ }^{2} \mathrm{D}_{\mathrm{jt}}+\gamma_{\mathrm{iu}}{ }^{2}\left(\mathrm{D}_{\mathrm{ut}} \mathrm{MR}_{\mathrm{t}}\right)+\gamma_{\mathrm{id}}{ }^{2}\left(\mathrm{D}_{\mathrm{dt}} \mathrm{MR}_{\mathrm{t}}\right)+€_{10 \mathrm{it}} \ldots . .(10) \quad \mathrm{i}=1, \ldots ., 6 ; \mathrm{j}=1, \ldots ., 5 .
\end{aligned}
$$

Where $D_{u} \& D_{d}$ are the dummy variables taking the values

$D_{\mathrm{u}}=1$ if $\mathrm{MR}_{\mathrm{t}}$ is positive

$$
=0 \text { otherwise }
$$

$\mathrm{D}_{\mathrm{d}}=1$ if $\mathrm{MR}_{\mathrm{t}}$ is non-positive

$=0$ otherwise

$\begin{aligned} & \text { 3.1.5. Model V: } \mathrm{R}_{\mathrm{it}}=\sum \beta_{\mathrm{ij}}{ }^{1} \mathrm{D}_{\mathrm{jt}}+\sum \gamma_{\mathrm{iju}}{ }^{1} \mathrm{D}_{\mathrm{jt}}\left(\mathrm{D}_{\mathrm{ut}} \mathrm{MR}_{\mathrm{t}}\right)+\sum \gamma_{\mathrm{ijd}}{ }^{1} \mathrm{D}_{\mathrm{jt}}\left(\mathrm{D}_{\mathrm{dt}} \mathrm{MR}_{\mathrm{t}}\right)+€_{11 \mathrm{it}} \ldots \ldots \ldots \\ & \mathrm{V}_{\mathrm{it}}=\sum \beta_{\mathrm{ij}}{ }^{2} \mathrm{D}_{\mathrm{jt}}+\sum \gamma_{\mathrm{iu}} \mathrm{D}_{\mathrm{jt}}\left(\mathrm{D}_{\mathrm{ut}} \mathrm{MR}_{\mathrm{t}}\right)+\sum \gamma_{\mathrm{id}}{ }^{2} \mathrm{D}_{\mathrm{jt}}\left(\mathrm{D}_{\mathrm{dt}} \mathrm{MR}_{\mathrm{t}}\right)+€_{12 \mathrm{it}} \ldots \ldots \ldots\end{aligned}$

2. $\quad i=1, \ldots ., 6 ; j=1, \ldots ., 5$.

' $\mathrm{i}$ ' denotes a particular stock index and ' $\mathrm{j}$ ' denotes a particular day of the week.

Model V is a conditional model that also includes slope interaction terms between the day of the week variables and up (down) excess market returns.

The error terms in the above five models are the classical error terms as they follow the assumptions of classical linear regression model. This implies that the error terms are assumed to be independent and identically distributed with a zero mean and constant variance.

\section{EMPIRICAL FINDINGS}

\subsection{Descriptive Statistics}

4.1.1. Intraday Returns: Except for Hang Seng and NSE Nifty, all the other four concerned stock indices are characterised by negative average return on Mondays. However, for NSE Nifty and Jakarta Composite Index, Monday suffers from the highest volatility as well. For NSE Nifty, all the days of the week yield positive average return, whereas, Taiwan Weighted Index exhibits negative average return for all the days of the week. In case of Jakarta Composite Index, Monday is the only day that yields negative average return. Moreover, Strait Times Index suffers from negative average returns on all the days of the week except on Friday. Friday has a maximum average return for Jakarta Composite Index, Strait Times Index and FTSE Bursa. For all the indices, the values of skewness and kurtosis reveal that the returns do not follow normal distribution. Further Jarque-Bera test of normality has been applied and its null hypothesis of presence of normal distribution has been rejected at both $5 \%$ and $1 \%$ levels of significance. 
4.1.2. Interday Returns: Except for Hang Seng and NSE Nifty, all the other concerned stock indices are characterised by negative average return on Mondays. Moreover, Monday also suffers from maximum volatility for all the indices except for Hang Seng and Kualalampur FTSE Bursa. For NSE Nifty, all the days of the week yield positive average return. Monday is the only day exhibiting negative average return for Jakarta Composite Index. Friday yields maximum average return for Strait Times Index, Jakarta Composite Index and Hang Seng. However, the values of skewness and kurtosis reveal that the returns do not follow normal distribution. Further Jarque-Bera test of normality has been applied and its null hypothesis of presence of normal distribution has been rejected at both $5 \%$ and $1 \%$ levels of significance.

\subsection{Unit Root Test}

The return series for all the indexes are tested for the presence of unit root. The study applies Augmented Dickey-Fuller test for the presence of non-stationarity. However, for all the indexes, the absolute values of the estimated t-statistic exceed 2 such that the null hypothesis of the presence of unit root is rejected. Moreover, the p-values also turn out to be lower than 0.01 and 0.05 such that the null hypothesis of the presence of unit roots is rejected at both 5\% and $1 \%$ levels of significance. Thus, the return series are stationary at level itself. The reason is that return is calculated as the first difference of the closing stock prices of the two consecutive days. Hence, it is integrated of order zero [I (0)] such that any empirical analysis can be done on the initial return series itself. Hence, the transformation of the return series is not required.

\subsection{Model I: No Market Risk Factor}

4.3.1. Intraday Returns: In this situation, Hang Seng and TSEC Weighted Index exhibit significant Monday effect. Jakarta Composite Index exhibits significant Tuesday, Wednesday and Weekend effects. Kualalampur FTSE Bursa Index exhibits Weekend effect. However, Strait Times Index has no such day-of-the-effect. Both Monday and Wednesday are statistically significant for TSEC Weighted Index to explain the expected intraday return.

4.3.2. Interday Returns: Hang Seng and Strait Times Index exhibit no such day of the week effect. For Jakarta Composite Index, all the days of the week, except Monday are statistically significant. Kualalampur FTSE Bursa and TSEC Weighted Index have significant Thursday and Wednesday effects respectively.

\subsection{Model II: Constant Market Risk Factor}

4.4.1. Intraday Return: In this model, Hang Seng yields both significant Monday and Weekend effects. However, except for Monday, all the days of the week turned out to be statistically significant in case of Jakarta Composite Index and Kualalampur FTSE Bursa. TSEC Weighted Index is characterized by significant Monday effect. However, there exists no such day-of-the-week effect for Strait Times Index and NSE Nifty.

4.4.2. Interday Returns: All the days of the week are statistically significant for Jakarta Composite Index. Kualalampur FTSE Bursa and Strait Times Index exhibit significant Thursday and Tuesday effects respectively. However, Hang Seng, TSEC Weighted Index and NSE Nifty have no such significant day-of-the-week effect.

For both the stock returns, Monday return is negative and Friday return is positive. However, for Hang Seng the reverse happens. All the market risk factors are positive and turn out to be statistically significant in explaining variation in the expected intraday and interday returns which is clear from their estimated $t$-statistics given in the parenthesis. This indicates that the concerned stock markets are less risky than the global market

\subsection{Model III: Market Risk Factor across the Days of the Week}

4.5.1. Intraday Return: Hang Seng and TSEC Weighted Index exhibit significant Monday effect. Except Monday, all the days of the week are statistically significant both for Jakarta Composite Index and Kualalampur FTSE Bursa. Other than Hang Seng, Monday yields negative average return for all the other indices. However, Strait Times Index and NSE Nifty have no such significant day-of-the-week effect.

4.5.2. Interday Return: All the days of the week are statistically significant for Jakarta Composite Index. Kualalampur FTSE Bursa and Strait Times Index have significant Thursday and Tuesday effects respectively. However, Hang Seng, TSEC Weighted Index and NSE Nifty exhibit no such significant day-of-the-week effect. However, all the market risk factors are positive and turn out to be statistically significant in explaining variation in the expected intraday and interday returns for all the days of the week which is clear from their estimated tstatistics given in the parenthesis. This indicates that the concerned stock markets are less risky than the global market for all the days of the week. 


\subsection{Model IV: Conditional Market Risk Factor}

4.6.1. Intraday Return: Hang Seng, TSEC Weighted Index and NSE Nifty are characterised by significant Monday effect. However, Jakarta Composite Index exhibits significant Tuesday, Wednesday and Weekend effects. Kualalampur FTSE Bursa has significant Thursday and Weekend effects. Moreover, Wednesday effect is prevalent in TSEC Weighted Index. Strait Times Index is the only index that has no such day-of-the-week effect. However, both the up and down market risk factors are statistically significant in three out of six indices (Hang Seng, Strait Times Index and NSE Nifty).

4.6.2. Interday Return: Jakarta Composite Index exhibits Tuesday, Wednesday and Weekend effects. Kualalampur FTSE Bursa and TSEC Weighted Index have Thursday and Wednesday effects respectively. However, Hang Seng, Strait Times Index and NSE Nifty exhibit no such day-of-the-week effect.

All the up market risk factors are statistically significant. However, the down market risk factor is statistically significant for four out of six indices (Hang Seng, Strait Times Index, TSEC Weighted Index and NSE Nifty).

\subsection{Model V: Conditional Market Risk Factor across the Days of the Week}

4.7.1. Intraday Return: Monday effect is detected in Hang Seng and TSEC Weighted Index. Jakarta Composite Index exhibits both Wednesday and Weekend effects. However, none of the other indices exhibit any such dayof-the-week effect.

However, for some days and for some indices, the market risk factor turns out to be negative implying that for that particular day, the corresponding stock market is more risky than the world market. For Hang Seng, none of the market risk factors are statistically significant.

4.7.2. Interday Return: Other than Monday, all the days of the week are statistically significant for Jakarta Composite Index. Wednesday effect is prevalent in NSE Nifty. However, no other indices exhibit any such dayof-the-week effect.

Most of the market risk factors are statistically significant in explaining the variation in the average interday return.

\section{CONCLUSION}

The paper takes into consideration both the conditional as well as unconditional market risk factors to analyze the day-of-the-week and intraday effects on the stock returns of 6 stock indices of some selected countries covering the Asia-Pacific Rim. In order to fulfil the objectives of the paper, five models are estimated where in each model the market risk factor is defined in different ways. However, the first model incorporates of no market risk factor. It is the simplest model. Hang Seng, Jakarta Composite Index, Kualalampur FTSE Bursa and TSEC Weighted Index exhibit day-of-the-week effect on the expected intra-day stock returns. However, Jakarta Composite Index is the only index exhibiting day-of-the-week effect on the expected inter-day stock returns. Model II incorporates a constant market risk factor. Hang Seng and TSEC Weighted Index exhibit Monday effect while considering the expected intraday stock returns. However, for Jakarta Composite Index, all the days of the week are statistically significant to explain the variation in the expected intraday-stock return, except Monday. However, while considering the interday-stock return, Hang-Seng Index, Nifty and TSEC Weighted Index have no such day-of-the-week effect. However, FTSE Bursa and Jakarta Composite index exhibit many such days-of-the-week effects. The market risk factors turn out to be positive implying that the corresponding stock market is less risky than the world stock market. Model III allows the market risk factor to vary across the days of the week. However, Model II and Model III exhibit same results. In Model III, Hang Seng Index and TSEC Weighted Index exhibit Monday effect, as in Model II in case of intraday stock return. However, for Kualalampur FTSE Bursa and Jakarta Composite Index, all the days of the week are statistically significant, except Monday. While considering the interday stock return, Jakarta Composite Index, Strait Times Index and Kualalampur FTSE Bursa have significant day-of-the-week effect. Model IV and Model V incorporate conditional market risk factors. For Model IV as well, Hang Seng and TSEC Weighted Indices exhibit Monday effect as in the previous models while considering the intraday stock returns along with NSE Nifty. While considering the interday return, the Jakarta Composite Index, TSEC Weighted Index and Kualalampur FTSE Bursa exhibit days-of-the-week effect. However, none of the indices exhibits significant Monday effect. In Model V, Kualalampur FTSE, TSEC Weighted Index and NSE Nifty have no such day-of-the-week effects to explain the variation in the expected intraday stock returns whereas, for the interday stock returns, Jakarta Composite and NSE Nifty Indices exhibit significant day-of-the-week effect. Hang Seng Index exhibits Monday effect in all the five models while considering the intraday stock return. It exhibits no such effects on the expected interday stock returns for all the five models. It is the only index where Monday is characterized by positive return for all the estimated five models. Moreover, Jakarta Composite Index is the only index in which all the days of the week are statistically significant in explaining the variation in intraday stock returns. Hence, 
while considering the conditional and unconditional market risk factors, it is found that the selected stock indices covering the Asia-Pacific Rim exhibit day-of-the-week and intraday effects on the expected stock returns.

\section{REFERENCES}

[1] Abdalla S.Z.S, Stock Return Seasonalities: Empirical Evidence from the Egyptian Stock Market, International Review of Business Research Papers 8(2), 2012, 163-180.

[2] Aksoy M. et. al. (2012). Day of the Week Anomaly during Financial Crisis: Portugal, Italy, Greece, Spain and Ireland. Available at: www.hippocampus.si/ISBN/978-961-6832-32-8/papers/aksoy1.pdf.

[3] Apolinario R.M.C., Santana O.M., Sales L.J., Caro A.R. Day of the Week Effect on European Stock Markets. International Research Journal of Finance and Economics, 2, 2006, 53-70.

[4] Basher S. A and Sadorsky P, Day-of-the-Week Effects in Emerging Stock Markets, Applied Economics Letters, 13, 2006, 621-628.

[5] Bayar A and Kan O.B, Day of the Week Effects: Recent Evidence from Nineteen Stock Markets. Central Bank Review 2, 2002, 77-90.

[6] Boudoukh J. and Richardson M. P, Industry Returns and the Fischer Effect, Journal of Finance, 49(5), 1994, 1595-1615.

[7] Chia R.C.J, Liew V.K.S, Wafa S.A. and Wafa S.K, Day-of-the-week effects in Selected East Asian stock markets, Economics Bulletin, 7(5), 2008, 1-8.

[8] Chia R. C. J and Liew V. K. S, Evidence on the Day-of-the-week Effect and Asymmetric Behavior in the Bombay Stock Exchange, The IUP Journal of Applied Finance, 16, 2010, 17-29.

[9] Chukwuogor C, An Econometric Analysis of African Stock Market: Annual Returns Analysis, Day-OfThe-Week Effect and Volatility of Returns. African Journal of Accounting, Economics, Finance and Banking Research, 1(1), 2007, 26- 43.

[10] Fama E.F, The Behaviour of Stock Market Prices, Journal of Business, 38, 1965, 161-178.

[11] Groth JC, Lewellen WG, Schlarbaum GG, Lease RC, An Analysis of Brokerage House Securities Recommendations, Financial Analysts Journal, 35(1), 1979, 32-40.

[12] Hussain F, Hamid K, Akash RSI and Khan M I, Day of the Week Effect and Stock Returns: Evidence from Karachi Stock Exchange-Pakistan. Far East Journal of Psychology and Business, 3(1), 2011, 25 30.

[13] Berument H. and Kiymaz H, The Day of the Week Effect on Stock Market Volatility, Journal of Economics and Finance, 25(2), 2001, 181-193.

[14] Kenourgios D, Samitas F, Papathanasiou S, The day of the week effect patterns on stock market return and volatility: Evidence for the Athens Stock Exchange, Proceedings of the 2nd Applied Financial Economics (AFE) International Conference on Financial Economics, Samos Island, Greece, 2005, 1-14.

[15] Kiymaz L and Berument H, The Day of the Week Effect on Stock Market Volatility and Volume: International Evidence, Review of Financial Economics 12, 2003, 363-380.

[16] Lyroudi, K., Subeniotis, D., \& Komisopoulos G, Market anomalies in the A.S.E.: The day of the week effect. Presentation at the European Finance Management Association, Annual Conference, 2002, London, UK.

[17] Rogalski R. J, New findings regarding day-of-the-week returns over trading and nontrading periods: A note. Journal of Finance, 35, 1984, 1603-1614.

[18] Smirlock M and Starks L, Day-of-the-Week and Intraday Effects in Stock Returns, Journal of Financial Economics, 17, 1986, 197-210.

[19] Tevdovski D, Mihajlov M, Sazdovski I, The Day of the Week Effect in South Eastern Europe Stock Markets, Annals of the Constantin Brâncuşi. University of Târgu Jiu, Economy Series, 3, 2012, 20-24.

[20] Yalcin Y. \& Yucel U.M. (2006). The Day-of-the-Week-Effect on Stock Market Volatility and Return: Evidence from Emerging Markets. Czech Journal of Economics and Finance, 56. Pg. 258-278.

APPENDIX

Table I: Descriptive Statistics Results

\begin{tabular}{|c|c|c|c|c|c|c|c|c|c|c|}
\hline & \multicolumn{10}{c|}{ HANG SENG INDEX } \\
\hline & \multicolumn{2}{|c|}{ Mon } & \multicolumn{2}{c|}{ Tues } & \multicolumn{2}{c|}{ Wed } & \multicolumn{2}{|c|}{ Thursday } & \multicolumn{2}{|c|}{ Friday } \\
\hline & $\begin{array}{c}\text { Intr } \\
\text { a }\end{array}$ & $\begin{array}{c}\text { Inte } \\
\mathbf{r}\end{array}$ & $\begin{array}{c}\text { Intr } \\
\text { ada }\end{array}$ & $\begin{array}{c}\text { Inte } \\
\mathbf{r}\end{array}$ & $\begin{array}{c}\text { Intr } \\
\mathbf{a}\end{array}$ & $\begin{array}{c}\text { Inte } \\
\mathbf{r}\end{array}$ & $\begin{array}{c}\text { Intr } \\
\mathbf{a}\end{array}$ & $\begin{array}{c}\text { Int } \\
\text { erd }\end{array}$ & $\begin{array}{c}\text { Int } \\
\text { rad }\end{array}$ & $\begin{array}{c}\text { Inter } \\
\text { day } \\
\text { day }\end{array}$ \\
day & $\mathbf{y}$ & day & day & day & day & ay & ay & \\
\hline $\begin{array}{c}\text { Mea } \\
\text { n }\end{array}$ & 0.27 & 0.00 & 0.27 & 0.02 & 0.27 & - & 0.26 & - & 0.2 & 0.04 \\
& & 6 & & & & 0.00 & & 0.0 & 6 & \\
\hline
\end{tabular}




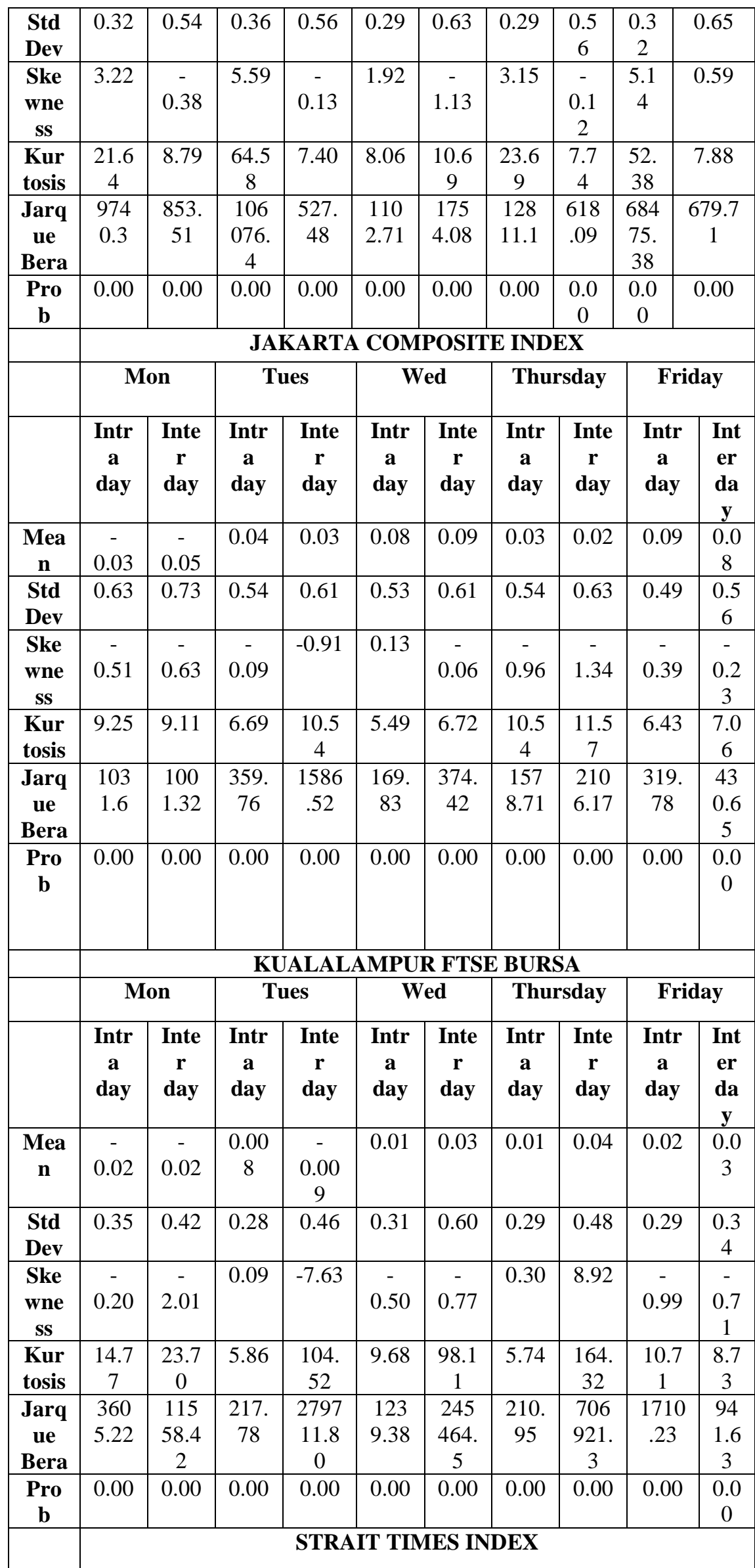




\begin{tabular}{|c|c|c|c|c|c|c|c|c|c|c|}
\hline & \multicolumn{2}{|c|}{ Mon } & \multicolumn{2}{|c|}{ Tues } & \multicolumn{2}{|c|}{ Wed } & \multicolumn{2}{|c|}{ Thursday } & \multicolumn{2}{|c|}{ Friday } \\
\hline & $\begin{array}{c}\text { Intr } \\
\text { a } \\
\text { day }\end{array}$ & $\begin{array}{c}\text { Inte } \\
\mathbf{r} \\
\text { day }\end{array}$ & $\begin{array}{c}\text { Intr } \\
\text { a } \\
\text { day }\end{array}$ & $\begin{array}{c}\text { Inte } \\
\mathbf{r} \\
\text { day }\end{array}$ & $\begin{array}{c}\text { Intr } \\
\text { a } \\
\text { day }\end{array}$ & $\begin{array}{c}\text { Inte } \\
\mathbf{r} \\
\text { day }\end{array}$ & $\begin{array}{c}\text { Intr } \\
\text { a } \\
\text { day }\end{array}$ & $\begin{array}{c}\text { Inte } \\
\mathbf{r} \\
\text { day }\end{array}$ & $\begin{array}{c}\text { Intr } \\
\text { a } \\
\text { day }\end{array}$ & $\begin{array}{l}\text { Int } \\
\text { er } \\
\text { da }\end{array}$ \\
\hline $\begin{array}{c}\text { Mea } \\
\text { n }\end{array}$ & $\begin{array}{c}- \\
0.02\end{array}$ & $\begin{array}{c}- \\
0.01\end{array}$ & $\begin{array}{c}- \\
0.00 \\
2\end{array}$ & 0.02 & $\begin{array}{c}- \\
0.00 \\
3\end{array}$ & 0.01 & $\begin{array}{c}- \\
0.03\end{array}$ & $\begin{array}{c}- \\
0.00 \\
1\end{array}$ & 0.01 & $\begin{array}{c}\mathbf{y} \\
0.0 \\
3\end{array}$ \\
\hline $\begin{array}{l}\text { Std } \\
\text { Dev }\end{array}$ & 0.53 & 0.59 & 0.43 & 0.46 & 0.44 & 0.50 & 0.46 & 0.53 & 0.43 & $\begin{array}{c}0.4 \\
8\end{array}$ \\
\hline $\begin{array}{c}\text { Ske } \\
\text { wne } \\
\text { sS }\end{array}$ & 0.3 & 0.15 & 0.13 & $\begin{array}{c}- \\
0.00 \\
5\end{array}$ & -0.2 & 0.73 & 0.7 & $\begin{array}{c}- \\
0.24\end{array}$ & $\begin{array}{c}- \\
1.28\end{array}$ & $\begin{array}{c}- \\
1.1 \\
6\end{array}$ \\
\hline $\begin{array}{l}\text { Kur } \\
\text { tosis }\end{array}$ & 7.46 & 6.14 & 6.13 & 5.74 & 8.99 & 9.30 & $\begin{array}{c}10.5 \\
0\end{array}$ & $\begin{array}{c}11.8 \\
0\end{array}$ & $\begin{array}{c}19.9 \\
4\end{array}$ & $\begin{array}{l}15 . \\
34\end{array}$ \\
\hline $\begin{array}{c}\text { Jarq } \\
\text { ue } \\
\text { Bera }\end{array}$ & $\begin{array}{c}540 . \\
66\end{array}$ & $\begin{array}{c}266 . \\
64\end{array}$ & $\begin{array}{c}270 . \\
87\end{array}$ & $\begin{array}{c}205 . \\
57\end{array}$ & $\begin{array}{c}997 . \\
77\end{array}$ & $\begin{array}{l}115 \\
8.65\end{array}$ & $\begin{array}{c}159 \\
5.76\end{array}$ & $\begin{array}{l}212 \\
5.89\end{array}$ & $\begin{array}{c}7989 \\
.50\end{array}$ & $\begin{array}{l}42 \\
89 . \\
28\end{array}$ \\
\hline \multirow[t]{4}{*}{$\begin{array}{c}\text { Pro } \\
\text { b }\end{array}$} & 0.00 & 0.00 & 0.00 & 0.00 & 0.00 & 0.00 & 0.00 & 0.00 & 0.00 & $\begin{array}{c}0.0 \\
0\end{array}$ \\
\hline & \multicolumn{10}{|c|}{ TSEC WEIGHTED INDEX } \\
\hline & \multicolumn{2}{|c|}{ Mon } & \multicolumn{2}{|c|}{ Tues } & \multicolumn{2}{|c|}{ Wed } & \multicolumn{2}{|c|}{ Thursday } & \multicolumn{2}{|c|}{ Friday } \\
\hline & $\begin{array}{c}\text { Intr } \\
\text { a } \\
\text { day }\end{array}$ & $\begin{array}{c}\text { Inte } \\
\mathbf{r} \\
\text { day }\end{array}$ & $\begin{array}{c}\text { Intr } \\
\text { a } \\
\text { day }\end{array}$ & $\begin{array}{c}\text { Inte } \\
\mathbf{r} \\
\text { day }\end{array}$ & $\begin{array}{c}\text { Intr } \\
\text { a } \\
\text { day }\end{array}$ & $\begin{array}{c}\text { Inte } \\
\mathbf{r} \\
\text { day }\end{array}$ & $\begin{array}{c}\text { Intr } \\
\text { a } \\
\text { day }\end{array}$ & $\begin{array}{c}\text { Inte } \\
\mathbf{r} \\
\text { day }\end{array}$ & $\begin{array}{c}\text { Intr } \\
\text { a } \\
\text { day }\end{array}$ & $\begin{array}{c}\text { Int } \\
\text { er } \\
\text { da }\end{array}$ \\
\hline $\begin{array}{c}\text { Mea } \\
\text { n }\end{array}$ & $\begin{array}{c}-\bar{c} \\
0.08\end{array}$ & $\begin{array}{c}- \\
0.02\end{array}$ & $\begin{array}{c}- \\
0.07\end{array}$ & -0.03 & $\begin{array}{c}- \\
0.03\end{array}$ & 0.06 & $\begin{array}{c}- \\
0.07\end{array}$ & $\begin{array}{c}- \\
0.00 \\
3\end{array}$ & $\begin{array}{c}- \\
0.04\end{array}$ & $\begin{array}{c}0.0 \\
2\end{array}$ \\
\hline $\begin{array}{l}\text { Std } \\
\text { Dev }\end{array}$ & 0.47 & 0.69 & 0.50 & 0.56 & 0.50 & 0.58 & 0.47 & 0.61 & 0.47 & $\begin{array}{c}0.5 \\
7\end{array}$ \\
\hline $\begin{array}{c}\text { Ske } \\
\text { wne } \\
\text { ss }\end{array}$ & $\begin{array}{c}- \\
0.55\end{array}$ & $\begin{array}{c}- \\
0.21\end{array}$ & 0.08 & -0.36 & 0.10 & 0.15 & $\begin{array}{c}- \\
0.12\end{array}$ & $\begin{array}{c}- \\
0.15\end{array}$ & 0.10 & $\begin{array}{c}- \\
0.4 \\
6\end{array}$ \\
\hline $\begin{array}{l}\text { Kur } \\
\text { tosis }\end{array}$ & 4.40 & 4.72 & 4.99 & 5.75 & 5.89 & 5.27 & 4.93 & 6.16 & 7.39 & $\begin{array}{c}5.1 \\
2\end{array}$ \\
\hline $\begin{array}{c}\text { Jarq } \\
\text { ue } \\
\text { Bera }\end{array}$ & $\begin{array}{c}83.3 \\
2\end{array}$ & $\begin{array}{c}82.3 \\
4\end{array}$ & $\begin{array}{c}107 . \\
71\end{array}$ & $\begin{array}{c}217 . \\
99\end{array}$ & $\begin{array}{c}226 . \\
30\end{array}$ & $\begin{array}{c}141 . \\
50\end{array}$ & $\begin{array}{c}100 . \\
68\end{array}$ & $\begin{array}{c}269 . \\
57\end{array}$ & $\begin{array}{c}513 . \\
75\end{array}$ & $\begin{array}{c}14 \\
2.3 \\
6\end{array}$ \\
\hline $\begin{array}{c}\text { Pro } \\
\text { b }\end{array}$ & 0.00 & 0.00 & 0.00 & 0.00 & 0.00 & 0.00 & 0.00 & 0.00 & 0.00 & $\begin{array}{c}0.0 \\
0\end{array}$ \\
\hline
\end{tabular}




\begin{tabular}{|c|c|c|c|c|c|c|c|c|c|c|}
\hline & \multicolumn{2}{|c|}{ Mon } & \multicolumn{2}{|c|}{ Tues } & \multicolumn{2}{|c|}{ Wed } & \multicolumn{2}{|c|}{ Thursday } & \multicolumn{2}{|c|}{ Friday } \\
\hline & $\begin{array}{c}\text { Intr } \\
\text { a } \\
\text { day }\end{array}$ & $\begin{array}{c}\text { Inte } \\
\mathbf{r} \\
\text { day }\end{array}$ & $\begin{array}{c}\text { Intr } \\
\text { a } \\
\text { day }\end{array}$ & $\begin{array}{c}\text { Inte } \\
\mathbf{r} \\
\text { day }\end{array}$ & $\begin{array}{c}\text { Intr } \\
\text { a } \\
\text { day }\end{array}$ & $\begin{array}{c}\text { Inte } \\
\mathbf{r} \\
\text { day }\end{array}$ & $\begin{array}{c}\text { Intr } \\
\text { a } \\
\text { day }\end{array}$ & $\begin{array}{c}\text { Inte } \\
\mathbf{r} \\
\text { day }\end{array}$ & $\begin{array}{l}\text { Intr } \\
\text { a } \\
\text { day }\end{array}$ & $\begin{array}{l}\text { Int } \\
\text { erd } \\
\text { ay }\end{array}$ \\
\hline $\begin{array}{c}\text { Mea } \\
\text { n }\end{array}$ & $\begin{array}{c}0.00 \\
1 \\
\end{array}$ & 0.02 & $\begin{array}{c}0.00 \\
8 \\
\end{array}$ & 0.02 & 0.01 & 0.03 & $\begin{array}{c}0.00 \\
5 \\
\end{array}$ & 0.01 & 0.01 & $\begin{array}{c}0.0 \\
3 \\
\end{array}$ \\
\hline $\begin{array}{l}\text { Std } \\
\text { Dev }\end{array}$ & 0.76 & 0.82 & 0.61 & 0.68 & 0.60 & 0.61 & 0.61 & 0.63 & 0.70 & $\begin{array}{c}0.7 \\
2 \\
\end{array}$ \\
\hline $\begin{array}{c}\text { Ske } \\
\text { wne } \\
\text { SS }\end{array}$ & 0.35 & $\begin{array}{c}- \\
0.49\end{array}$ & 0.16 & -1.87 & $\begin{array}{c}- \\
0.10\end{array}$ & $\begin{array}{c}- \\
0.06\end{array}$ & $\begin{array}{c}- \\
0.38\end{array}$ & $\begin{array}{c}- \\
0.36\end{array}$ & $\begin{array}{c}- \\
0.99\end{array}$ & $\begin{array}{c}- \\
0.9 \\
5\end{array}$ \\
\hline $\begin{array}{l}\text { Kur } \\
\text { tosis }\end{array}$ & $\begin{array}{c}19.3 \\
4\end{array}$ & $\begin{array}{c}21.6 \\
8\end{array}$ & 6.83 & $\begin{array}{c}27.2 \\
6\end{array}$ & 5.89 & 5.69 & 5.38 & 5.18 & $\begin{array}{c}11.6 \\
5\end{array}$ & $\begin{array}{l}10 . \\
91 \\
\end{array}$ \\
\hline $\begin{array}{c}\text { Jarq } \\
\text { ue } \\
\text { Bera }\end{array}$ & $\begin{array}{l}711 \\
6.79\end{array}$ & $\begin{array}{l}930 \\
0.52\end{array}$ & $\begin{array}{c}372 . \\
75\end{array}$ & $\begin{array}{l}1519 \\
4.67\end{array}$ & $\begin{array}{c}224 . \\
05\end{array}$ & $\begin{array}{c}192 . \\
53\end{array}$ & $\begin{array}{c}166 . \\
51\end{array}$ & $\begin{array}{c}140 . \\
40\end{array}$ & $\begin{array}{c}208 \\
1.74\end{array}$ & $\begin{array}{c}175 \\
0.2 \\
5\end{array}$ \\
\hline $\begin{array}{c}\text { Pro } \\
\text { b }\end{array}$ & 0.00 & 0.00 & 0.00 & 0.00 & 0.00 & 0.00 & 0.00 & 0.00 & 0.00 & $\begin{array}{c}0.0 \\
0\end{array}$ \\
\hline
\end{tabular}

Table II: Unit Root Test Results

\begin{tabular}{|c|c|c|c|c|c|c|c|c|c|c|c|c|}
\hline & \multicolumn{2}{|c|}{$\begin{array}{l}\text { Hang } \\
\text { Seng }\end{array}$} & \multicolumn{2}{|c|}{$\begin{array}{c}\text { Jakarta } \\
\text { Composi } \\
\text { te Index }\end{array}$} & \multicolumn{2}{|c|}{$\begin{array}{c}\text { Kualalamp } \\
\text { ur FTSE } \\
\text { Bursa }\end{array}$} & \multicolumn{2}{|c|}{$\begin{array}{l}\text { Strait Times } \\
\text { Index }\end{array}$} & \multicolumn{2}{|c|}{$\begin{array}{c}\text { TSEC } \\
\text { Weighted } \\
\text { Index }\end{array}$} & \multicolumn{2}{|c|}{ NSE Nifty } \\
\hline & $\begin{array}{c}\text { Int } \\
\text { ra }\end{array}$ & $\begin{array}{l}\text { Int } \\
\text { er }\end{array}$ & $\begin{array}{c}\text { Int } \\
\text { ra }\end{array}$ & $\begin{array}{l}\text { In } \\
\text { te } \\
\text { r }\end{array}$ & $\begin{array}{c}\text { Intr } \\
\mathbf{a}\end{array}$ & $\begin{array}{c}\text { Inte } \\
\mathbf{r}\end{array}$ & Intra & $\begin{array}{c}\text { Inte } \\
\mathbf{r}\end{array}$ & Intra & $\begin{array}{c}\text { Inte } \\
\mathbf{r}\end{array}$ & $\begin{array}{c}\text { Intr } \\
\mathbf{a}\end{array}$ & $\begin{array}{c}\text { Inte } \\
\mathbf{r}\end{array}$ \\
\hline $\begin{array}{c}\text { AD } \\
\text { F } \\
\text { Test }\end{array}$ & $\begin{array}{l}7.5 \\
3 *\end{array}$ & $\begin{array}{l}54 . \\
1 *\end{array}$ & 52. & $\begin{array}{r}49 \\
9\end{array}$ & $\begin{array}{c}49.6 \\
8 *\end{array}$ & $\begin{array}{c}64.4 \\
7 *\end{array}$ & $\begin{array}{c}57.33 \\
*\end{array}$ & $\begin{array}{c}38.4 \\
*\end{array}$ & $\begin{array}{l}61.79 \\
*\end{array}$ & $\begin{array}{c}53.3 \\
4 *\end{array}$ & $\begin{array}{c}53.6 \\
4 *\end{array}$ & $\begin{array}{c}- \\
53.6 \\
0 *\end{array}$ \\
\hline Test & $3^{*}$ & $1 *$ & $21^{*}$ & .9 & & & & & & & & \\
\hline $\begin{array}{c}\text { p- } \\
\text { valu } \\
\text { e }\end{array}$ & $\begin{array}{c}0.0 \\
0\end{array}$ & $\begin{array}{c}0.0 \\
0\end{array}$ & $\begin{array}{c}0.0 \\
0\end{array}$ & $\begin{array}{c}0 . \\
00\end{array}$ & 0.00 & 0.00 & 0.00 & 0.00 & 0.00 & $\overline{0.00}$ & 0.00 & 0.00 \\
\hline
\end{tabular}

*Significant at $1 \%$ level of significance

Table III: No Market Risk Factor (Model I)

\begin{tabular}{|c|c|c|c|c|c|c|c|c|c|c|c|c|}
\hline & \multicolumn{2}{|c|}{$\begin{array}{l}\text { Hang } \\
\text { Seng }\end{array}$} & \multicolumn{2}{|c|}{$\begin{array}{c}\text { Jakarta } \\
\text { Composit } \\
\text { e Index } \\
\end{array}$} & \multicolumn{2}{|c|}{$\begin{array}{c}\text { Kualalamp } \\
\text { ur FTSE } \\
\text { Bursa } \\
\end{array}$} & \multicolumn{2}{|c|}{$\begin{array}{l}\text { Strait } \\
\text { Times } \\
\text { Index }\end{array}$} & \multicolumn{2}{|c|}{$\begin{array}{c}\text { TSEC } \\
\text { Weighted } \\
\text { Index } \\
\end{array}$} & \multicolumn{2}{|c|}{ NSE Nifty } \\
\hline & $\begin{array}{c}\text { Intr } \\
\mathbf{a}\end{array}$ & $\begin{array}{c}\text { Inte } \\
\mathbf{r}\end{array}$ & $\begin{array}{c}\text { Intr } \\
\mathbf{a}\end{array}$ & $\begin{array}{c}\text { Inte } \\
\mathbf{r}\end{array}$ & $\begin{array}{c}\text { Intr } \\
\mathbf{a}\end{array}$ & $\begin{array}{c}\text { Inte } \\
\mathbf{r}\end{array}$ & $\begin{array}{c}\text { Intr } \\
\text { a }\end{array}$ & $\begin{array}{c}\text { Inte } \\
\mathbf{r}\end{array}$ & $\begin{array}{c}\text { Intr } \\
\mathbf{a}\end{array}$ & $\begin{array}{c}\text { Inte } \\
\mathbf{r}\end{array}$ & $\begin{array}{c}\text { Intr } \\
\mathbf{a}\end{array}$ & $\begin{array}{l}\text { Int } \\
\text { er }\end{array}$ \\
\hline $\begin{array}{l}\text { M } \\
\text { on }\end{array}$ & $\begin{array}{c}0.2 \\
7 * \\
(21 . \\
54)\end{array}$ & $\begin{array}{c}0.0 \\
3 \\
(1.3 \\
5)\end{array}$ & $\begin{array}{c}- \\
0.0 \\
3 \\
(- \\
1.4 \\
9)\end{array}$ & $\begin{array}{c}- \\
0.0 \\
5^{*} \\
(- \\
2.1 \\
1)\end{array}$ & $\begin{array}{c}- \\
0.0 \\
2 \\
(- \\
1.6 \\
8)\end{array}$ & $\begin{array}{c}- \\
0.02 \\
(- \\
0.91 \\
)\end{array}$ & $\begin{array}{c}- \\
0.0 \\
2 \\
(- \\
1.4 \\
1)\end{array}$ & $\begin{array}{c}- \\
0.0 \\
1 \\
(- \\
0.7 \\
7)\end{array}$ & $\begin{array}{c}- \\
0.0 \\
8^{*} \\
(- \\
4.4 \\
0)\end{array}$ & $\begin{array}{c}- \\
0.02 \\
(- \\
1.04 \\
)\end{array}$ & $\begin{array}{c}0.00 \\
1 \\
(0.0 \\
5)\end{array}$ & $\begin{array}{c}0.0 \\
2 \\
(0.7 \\
6)\end{array}$ \\
\hline $\begin{array}{c}\text { T } \\
\text { ue } \\
\mathrm{s}\end{array}$ & $\begin{array}{c}0.0 \\
03 \\
(0.1 \\
6)\end{array}$ & $\begin{array}{c}- \\
0.0 \\
3 \\
(- \\
0.8 \\
4) \\
\end{array}$ & $\begin{array}{c}0.0 \\
7^{*} \\
(2.3 \\
0)\end{array}$ & $\begin{array}{c}\mathbf{0 . 0} \\
\mathbf{8}^{*} \\
(2.3 \\
6)\end{array}$ & $\begin{array}{c}0.0 \\
3 \\
(1.6 \\
5)\end{array}$ & $\begin{array}{c}0.00 \\
8 \\
(0.2 \\
9)\end{array}$ & $\begin{array}{c}0.0 \\
2 \\
(0.9 \\
3)\end{array}$ & $\begin{array}{c}0.0 \\
3 \\
(1.2 \\
3)\end{array}$ & $\begin{array}{c}0.0 \\
1 \\
(0.6 \\
0)\end{array}$ & $\begin{array}{c}- \\
0.00 \\
4 \\
(- \\
0.11 \\
)\end{array}$ & $\begin{array}{c}0.00 \\
7 \\
(0.1 \\
9)\end{array}$ & $\begin{array}{c}- \\
0.0 \\
005 \\
(- \\
0.0 \\
1)\end{array}$ \\
\hline $\begin{array}{l}\text { W } \\
\text { ed }\end{array}$ & $\begin{array}{c}0.0 \\
03 \\
(0.1\end{array}$ & $\begin{array}{c}- \\
0.0 \\
08\end{array}$ & $\begin{array}{l}0.1 \\
1 * \\
(3.6\end{array}$ & $\begin{array}{l}0.1 \\
4^{*} \\
(3.9\end{array}$ & $\begin{array}{c}0.0 \\
3 \\
(1.8\end{array}$ & $\begin{array}{c}0.04 \\
(1.7 \\
1)\end{array}$ & $\begin{array}{c}0.0 \\
2 \\
(0.8\end{array}$ & $\begin{array}{c}0.0 \\
2 \\
(0.9\end{array}$ & $\begin{array}{c}\mathbf{0 . 0} \\
\mathbf{5}^{*} \\
(\mathbf{2 . 0}\end{array}$ & $\begin{array}{c}\mathbf{0 . 0 8} \\
* \\
(2.4\end{array}$ & $\begin{array}{c}0.01 \\
(0.4 \\
1)\end{array}$ & $\begin{array}{c}0.0 \\
1 \\
(0.2\end{array}$ \\
\hline
\end{tabular}




\begin{tabular}{|c|c|c|c|c|c|c|c|c|c|c|c|c|}
\hline & $9)$ & $(-$ & $\mathbf{3})$ & $\mathbf{8})$ & $6)$ & & $8)$ & $3)$ & $\mathbf{6})$ & $\mathbf{9 )}$ & & $9)$ \\
& & 0.2 & & & & & & & & & & \\
\hline $\mathbf{T}$ & - & - & 0.0 & $\mathbf{0 . 0}$ & $\mathbf{0 . 0}$ & $\mathbf{0 . 0 5}$ & - & 0.0 & 0.0 & 0.02 & 0.00 & - \\
$\mathbf{h}$ & 0.0 & 0.0 & 6 & $\mathbf{8}^{*}$ & $\mathbf{3}^{*}$ & $*$ & 0.0 & 1 & 2 & $(0.6$ & 3 & 0.0 \\
$\mathbf{u r}$ & 1 & 3 & $(1.9$ & $\mathbf{( 2 . 1}$ & $\mathbf{( 2 . 1}$ & $\mathbf{( 2 . 0}$ & 88 & $(0.4$ & $(0.6$ & $3)$ & $(0.0$ & 09 \\
$\mathbf{S}$ & $(-$ & $(-$ & $7)$ & $\mathbf{6})$ & $\mathbf{2})$ & $\mathbf{8})$ & $(-$ & $9)$ & $4)$ & & $9)$ & $(-$ \\
& 0.8 & 1.0 & & & & & 0.3 & & & & & 0.2 \\
& $4)$ & $2)$ & & & & & $3)$ & & & & & $2)$ \\
\hline $\mathbf{F r}$ & - & - & $\mathbf{0 . 1}$ & $\mathbf{0 . 1}$ & $\mathbf{0 . 0}$ & 0.05 & 0.0 & 0.0 & 0.0 & 0.05 & 0.01 & 0.0 \\
$\mathbf{i}$ & 0.0 & 0.0 & $\mathbf{2}^{*}$ & $\mathbf{3}^{*}$ & $\mathbf{4}^{*}$ & $(1.8$ & 4 & 4 & 4 & $(1.5$ & $(0.3$ & 1 \\
& 07 & 5 & $\mathbf{( 3 . 9}$ & $\mathbf{( 3 . 7}$ & $\mathbf{( 2 . 5}$ & $0)$ & $(1.4$ & $(1.5$ & $(1.7$ & $3)$ & $3)$ & $(0.3$ \\
& $(-$ & $(-$ & $\mathbf{1}$ & $\mathbf{9})$ & $\mathbf{9})$ & & $7)$ & $6)$ & $2)$ & & & $6)$ \\
& 0.4 & 1.5 & & & & & & & & & & \\
& $1)$ & $5)$ & & & & & & & & & & \\
\hline
\end{tabular}

*Significant at $1 \%$ level of significance

[1] Table IV: Constant Market Risk Factor (Model II)

\begin{tabular}{|c|c|c|c|c|c|c|c|c|c|c|c|c|}
\hline & \multicolumn{2}{|c|}{ Hang Seng } & \multicolumn{2}{|c|}{$\begin{array}{c}\text { Jakarta } \\
\text { Composite } \\
\text { Index }\end{array}$} & \multicolumn{2}{|c|}{$\begin{array}{c}\text { Kualalamp } \\
\text { ur FTSE } \\
\text { Bursa }\end{array}$} & \multicolumn{2}{|c|}{$\begin{array}{l}\text { Strait } \\
\text { Times } \\
\text { Index }\end{array}$} & \multicolumn{2}{|c|}{$\begin{array}{c}\text { TSEC } \\
\text { Weighted } \\
\text { Index }\end{array}$} & \multicolumn{2}{|c|}{$\begin{array}{l}\text { NSE } \\
\text { Nifty }\end{array}$} \\
\hline & $\begin{array}{c}\text { Intr } \\
\mathbf{a}\end{array}$ & $\begin{array}{c}\text { Inte } \\
\mathbf{r}\end{array}$ & $\begin{array}{c}\text { Intr } \\
\mathbf{a}\end{array}$ & Inter & $\begin{array}{c}\text { Intr } \\
\mathbf{a}\end{array}$ & $\begin{array}{c}\text { Inte } \\
\mathbf{r}\end{array}$ & $\begin{array}{c}\text { Intr } \\
\mathbf{a}\end{array}$ & $\begin{array}{c}\text { Inte } \\
\mathbf{r}\end{array}$ & $\begin{array}{c}\text { Intr } \\
\mathbf{a}\end{array}$ & $\begin{array}{c}\text { Inte } \\
\mathbf{r}\end{array}$ & $\begin{array}{c}\text { Int } \\
\text { ra }\end{array}$ & $\begin{array}{l}\text { Int } \\
\text { er }\end{array}$ \\
\hline Mon & $\begin{array}{c}0.19 \\
* \\
(17.2 \\
3)\end{array}$ & $\begin{array}{c}0.00 \\
2 \\
(0.1 \\
3)\end{array}$ & $\begin{array}{c}0.03 \\
(- \\
1.87 \\
)\end{array}$ & $\begin{array}{c}\mathbf{0 . 0 4} \\
* \\
(- \\
2.39)\end{array}$ & $\begin{array}{c}-0.02 \\
(- \\
1.72)\end{array}$ & $\begin{array}{c}0.02 \\
(- \\
1.62 \\
)\end{array}$ & $\begin{array}{c}-0.01 \\
(- \\
1.11)\end{array}$ & $\begin{array}{c}0.02 \\
(- \\
1.40 \\
)\end{array}$ & $\begin{array}{c}0.04 \\
(- \\
2.86 \\
)\end{array}$ & $\begin{array}{c}0.02 \\
(- \\
1.06 \\
)\end{array}$ & $\begin{array}{c}0.0 \\
04 \\
(- \\
0.2 \\
8)\end{array}$ & $\begin{array}{c}0.0 \\
1 \\
(- \\
0.7 \\
4)\end{array}$ \\
\hline Tues & $\begin{array}{c}0.01 \\
(0.64 \\
)\end{array}$ & $\begin{array}{l}0.01 \\
(0.5 \\
6)\end{array}$ & $\begin{array}{c}\mathbf{0 . 0 7} \\
* \\
(3.2 \\
6)\end{array}$ & $\begin{array}{c}\mathbf{0 . 0 8} \\
* \\
(3.22 \\
)\end{array}$ & $\begin{array}{c}0.03 \\
(2.14 \\
)\end{array}$ & $\begin{array}{c}0.03 \\
(1.5 \\
8)\end{array}$ & $\begin{array}{c}0.03 \\
(1.57 \\
)\end{array}$ & $\begin{array}{c}0.05 \\
(2.1 \\
5)\end{array}$ & $\begin{array}{c}0.02 \\
(1.0 \\
0)\end{array}$ & $\begin{array}{c}0.02 \\
(0.8 \\
4)\end{array}$ & $\begin{array}{c}0.0 \\
3 \\
(1 . \\
54)\end{array}$ & $\begin{array}{c}0.0 \\
5 \\
(1 . \\
77)\end{array}$ \\
\hline Wed & $\begin{array}{c}0.00 \\
6 \\
(0.43 \\
)\end{array}$ & $\begin{array}{c}0.00 \\
3 \\
(0.1 \\
2)\end{array}$ & $\begin{array}{c}\mathbf{0 . 0 6} \\
* \\
(3.0 \\
\mathbf{0})\end{array}$ & $\begin{array}{c}\mathbf{0 . 0 7} \\
* \\
(\mathbf{2 . 8 8} \\
)\end{array}$ & $\begin{array}{c}0.03 \\
(2.03 \\
)\end{array}$ & $\begin{array}{c}0.04 \\
(1.7 \\
8)\end{array}$ & $\begin{array}{c}0.01 \\
(0.89 \\
)\end{array}$ & $\begin{array}{c}0.03 \\
(1.1 \\
9)\end{array}$ & $\begin{array}{c}0.03 \\
(1.4 \\
9)\end{array}$ & $\begin{array}{c}0.04 \\
(1.4 \\
8)\end{array}$ & $\begin{array}{c}0.0 \\
2 \\
(0 . \\
83)\end{array}$ & $\begin{array}{c}0.0 \\
2 \\
(0 . \\
70)\end{array}$ \\
\hline $\begin{array}{c}\text { Thu } \\
\text { rs }\end{array}$ & $\begin{array}{c}- \\
0.00 \\
8 \\
(- \\
0.50)\end{array}$ & $\begin{array}{c}0.00 \\
7 \\
(0.2 \\
9)\end{array}$ & $\begin{array}{c}\mathbf{0 . 0 5} \\
* \\
(2.3 \\
1)\end{array}$ & $\begin{array}{c}0.06 \\
* \\
(2.46 \\
)\end{array}$ & $\begin{array}{c}0.03 \\
(2.17 \\
)\end{array}$ & $\begin{array}{l}0.05 \\
(2.6 \\
9)\end{array}$ & $\begin{array}{c}0.00 \\
8 \\
(0.45 \\
)\end{array}$ & $\begin{array}{c}0.03 \\
(1.3 \\
2)\end{array}$ & $\begin{array}{c}0.01 \\
(0.6 \\
2)\end{array}$ & $\begin{array}{c}0.02 \\
(0.9 \\
9)\end{array}$ & $\begin{array}{c}0.0 \\
1 \\
(0 . \\
53)\end{array}$ & $\begin{array}{c}0.0 \\
3 \\
(1 . \\
09)\end{array}$ \\
\hline Fri & $\begin{array}{c}- \\
0.00 \\
08 \\
(- \\
0.05)\end{array}$ & $\begin{array}{c}- \\
0.02 \\
(- \\
0.73 \\
)\end{array}$ & $\begin{array}{c}\mathbf{0 . 0 8} \\
* \\
(3.7 \\
9)\end{array}$ & $\begin{array}{c}\mathbf{0 . 0 7} \\
* \\
(2.89 \\
)\end{array}$ & $\begin{array}{c}0.04 \\
(2.60 \\
)\end{array}$ & $\begin{array}{c}0.03 \\
(1.7 \\
4)\end{array}$ & $\begin{array}{c}0.02 \\
(1.09 \\
)\end{array}$ & $\begin{array}{c}0.03 \\
(1.3 \\
2)\end{array}$ & $\begin{array}{c}0.02 \\
(1.3 \\
0)\end{array}$ & $\begin{array}{c}0.02 \\
(0.9 \\
9)\end{array}$ & $\begin{array}{c}0.0 \\
1 \\
(0 . \\
77)\end{array}$ & $\begin{array}{c}0.0 \\
2 \\
(0 . \\
72)\end{array}$ \\
\hline MR & $\begin{array}{c}0.28 \\
* \\
(31.3 \\
4)\end{array}$ & $\begin{array}{c}0.53 \\
* \\
(50 . \\
48)\end{array}$ & $\begin{array}{c}0.56 \\
* \\
(63 . \\
32)\end{array}$ & $\begin{array}{c}0.55 \\
* \\
(53.3 \\
1)\end{array}$ & $\begin{array}{c}0.29 \\
(37.4 \\
5)\end{array}$ & $\begin{array}{l}0.40 \\
(42 . \\
94)\end{array}$ & $\begin{array}{c}0.48 \\
(53.4 \\
1)\end{array}$ & $\begin{array}{c}0.43 \\
(36 . \\
50)\end{array}$ & $\begin{array}{l}0.50 \\
(54 . \\
63)\end{array}$ & $\begin{array}{l}0.54 \\
(50 . \\
74)\end{array}$ & $\begin{array}{c}0.6 \\
6 \\
(77 \\
.74 \\
)\end{array}$ & $\begin{array}{c}0.6 \\
3 \\
(55 \\
.16 \\
)\end{array}$ \\
\hline
\end{tabular}

*Significant at $1 \%$ level of significance

Table V: Market Risk Factor across the Days of the Week (Model III)

\begin{tabular}{|l|l|c|c|c|c|c|}
\hline Hang Seng & $\begin{array}{c}\text { Jakarta } \\
\text { Composite } \\
\text { Index }\end{array}$ & $\begin{array}{c}\text { Kualalam } \\
\text { pur FTSE } \\
\text { Bursa }\end{array}$ & $\begin{array}{c}\text { Strait } \\
\text { Times } \\
\text { Index }\end{array}$ & $\begin{array}{c}\text { TSEC } \\
\text { Weighted } \\
\text { Index }\end{array}$ & NSE Nifty \\
\hline
\end{tabular}




\begin{tabular}{|c|c|c|c|c|c|c|c|c|c|c|c|c|}
\hline & $\begin{array}{l}\text { Intr } \\
\mathbf{a}\end{array}$ & $\begin{array}{l}\text { Inte } \\
\mathbf{r}\end{array}$ & $\begin{array}{c}\text { Intr } \\
\mathbf{a}\end{array}$ & $\begin{array}{c}\text { Inte } \\
\mathbf{r}\end{array}$ & $\begin{array}{c}\text { Intr } \\
\mathbf{a}\end{array}$ & $\begin{array}{c}\text { Inte } \\
\mathbf{r}\end{array}$ & $\begin{array}{c}\text { Intr } \\
\mathbf{a}\end{array}$ & $\begin{array}{c}\text { Inte } \\
\mathbf{r}\end{array}$ & $\begin{array}{c}\text { Intr } \\
\mathbf{a}\end{array}$ & $\begin{array}{c}\text { Inte } \\
\mathbf{r}\end{array}$ & $\begin{array}{c}\text { Intr } \\
\mathbf{a}\end{array}$ & $\begin{array}{c}\text { Inte } \\
\mathbf{r}\end{array}$ \\
\hline $\begin{array}{c}\text { Mo } \\
\text { n }\end{array}$ & $\begin{array}{c}.19 \\
* \\
(15.8 \\
1)\end{array}$ & $\begin{array}{c}0.03 \\
(1.67 \\
)\end{array}$ & $\begin{array}{c}-0.02 \\
(- \\
1.83)\end{array}$ & $\begin{array}{c}\mathbf{0 . 0 4} \\
* \\
(- \\
\text { 2.35) }\end{array}$ & $\begin{array}{c}0.01 \\
(- \\
1.65 \\
)\end{array}$ & $\begin{array}{c}- \\
0.02 \\
(- \\
1.52 \\
)\end{array}$ & $\begin{array}{c}0.01 \\
(- \\
0.92 \\
)\end{array}$ & $\begin{array}{c}0.02 \\
(- \\
1.48 \\
)\end{array}$ & $\begin{array}{c}- \\
\mathbf{0 . 0 4} \\
* \\
(- \\
2.66)\end{array}$ & $\begin{array}{c}-0.02 \\
(- \\
1.02)\end{array}$ & $\begin{array}{c}- \\
0.00 \\
5 \\
(- \\
0.32 \\
)\end{array}$ & $\begin{array}{c}0.02 \\
(- \\
0.94 \\
)\end{array}$ \\
\hline $\begin{array}{l}\text { Tu } \\
\text { es }\end{array}$ & $\begin{array}{c}-0.01 \\
(- \\
0.84)\end{array}$ & $\begin{array}{c}-0.01 \\
(- \\
0.56)\end{array}$ & $\begin{array}{c}\mathbf{0 . 0 6} \\
* \\
(3.25 \\
)\end{array}$ & $\begin{array}{c}\mathbf{0 . 0 8} \\
* \\
(3.19 \\
)\end{array}$ & $\begin{array}{c}\mathbf{0 . 0 3} \\
* \\
(2.0 \\
9) \\
\end{array}$ & $\begin{array}{c}0.03 \\
(1.5 \\
3)\end{array}$ & $\begin{array}{c}0.02 \\
(1.4 \\
3)\end{array}$ & $\begin{array}{c}\mathbf{0 . 0 5} \\
* \\
(2.1 \\
5) \\
\end{array}$ & $\begin{array}{c}1.20 \\
)\end{array}$ & $\begin{array}{c}0.02 \\
0.74 \\
)\end{array}$ & $\begin{array}{c}0.03 \\
(1.6 \\
2)\end{array}$ & $\begin{array}{c}0.05 \\
(1.9 \\
3)\end{array}$ \\
\hline $\begin{array}{c}\text { We } \\
\text { d }\end{array}$ & $\begin{array}{c}0.01 \\
(0.86 \\
)\end{array}$ & $\begin{array}{c}-0.02 \\
(- \\
0.97)\end{array}$ & $\begin{array}{c}\mathbf{0 . 0 6} \\
* \\
(3.02 \\
) \\
\end{array}$ & $\begin{array}{c}0.07 \\
* \\
(2.90 \\
)\end{array}$ & $\begin{array}{c}\mathbf{0 . 0 3} \\
* \\
(1.9 \\
\mathbf{8}) \\
\end{array}$ & $\begin{array}{l}0.03 \\
(1.4 \\
6)\end{array}$ & $\begin{array}{c}0.01 \\
(0.7 \\
4)\end{array}$ & $\begin{array}{c}0.03 \\
(1.2 \\
5)\end{array}$ & $\begin{array}{c}1.38 \\
)\end{array}$ & $\begin{array}{c}0.04 \\
1.52 \\
)\end{array}$ & $\begin{array}{c}0.02 \\
(0.8 \\
8)\end{array}$ & $\begin{array}{c}0.02 \\
(0.9 \\
5)\end{array}$ \\
\hline $\begin{array}{l}\text { Th } \\
\text { urs }\end{array}$ & $\begin{array}{c}0.00 \\
8 \\
(0.47 \\
) \\
\end{array}$ & $\begin{array}{c}-0.02 \\
(- \\
0.83)\end{array}$ & $\begin{array}{c}\mathbf{0 . 0 5} \\
* \\
(2.30 \\
) \\
\end{array}$ & $\begin{array}{c}0.06 \\
* \\
(2.44 \\
)\end{array}$ & $\begin{array}{c}\mathbf{0 . 0 3} \\
* \\
(2.1 \\
3)\end{array}$ & $\begin{array}{c}\mathbf{0 . 0 5} \\
* \\
(2.6 \\
4)\end{array}$ & $\begin{array}{c}0.00 \\
2 \\
(0.1 \\
2) \\
\end{array}$ & $\begin{array}{c}(1.3 \\
6)\end{array}$ & $\begin{array}{c}0.00 \\
6 \\
(0.31 \\
) \\
\end{array}$ & $\begin{array}{c}0.02 \\
0.95 \\
)\end{array}$ & $\begin{array}{c}0.01 \\
(0.5 \\
6)\end{array}$ & $\begin{array}{c}0.03 \\
(1.2 \\
2)\end{array}$ \\
\hline Fri & $\begin{array}{c}0.01 \\
(0.56 \\
)\end{array}$ & $\begin{array}{c}-0.05 \\
(- \\
1.78)\end{array}$ & $\begin{array}{c}0.08 \\
* \\
(4.10 \\
) \\
\end{array}$ & $\begin{array}{c}0.07 \\
* \\
(2.91 \\
)\end{array}$ & $\begin{array}{c}\mathbf{0 . 0 4} \\
* \\
(2.6 \\
0) \\
\end{array}$ & $\begin{array}{c}0.04 \\
(1.9 \\
3)\end{array}$ & $\begin{array}{c}0.02 \\
(0.9 \\
7)\end{array}$ & $\begin{array}{c}(1.3 \\
4)\end{array}$ & $\begin{array}{c}0.02 \\
(1.04 \\
)\end{array}$ & $\begin{array}{c}0.02 \\
0.93 \\
)^{\prime}\end{array}$ & $\begin{array}{c}0.02 \\
(0.8 \\
1)\end{array}$ & $\begin{array}{c}0.02 \\
(0.7 \\
4)\end{array}$ \\
\hline $\begin{array}{c}\mathbf{M o} \\
\mathbf{n} \\
\mathbf{M} \\
\mathbf{R}\end{array}$ & $\begin{array}{c}0.30 \\
* \\
(14.5 \\
4)\end{array}$ & $\begin{array}{c}0.06 \\
(0.85 \\
)\end{array}$ & $\begin{array}{c}0.64 \\
* \\
(34.5 \\
4)\end{array}$ & $\begin{array}{c}0.59 \\
* \\
(26.7 \\
7)\end{array}$ & $\begin{array}{c}0.38 \\
* \\
(21 . \\
74)\end{array}$ & $\begin{array}{c}0.31 \\
* \\
(14 . \\
37)\end{array}$ & $\begin{array}{c}0.59 \\
* \\
(30 . \\
52)\end{array}$ & $*$ & $\begin{array}{c}0.53 \\
* \\
(24.2 \\
7)\end{array}$ & $\begin{array}{c}0.60 \\
* \\
(25.8 \\
3)\end{array}$ & $\begin{array}{c}0.75 \\
* \\
(42 . \\
38)\end{array}$ & $\begin{array}{c}0.70 \\
* \\
(29 . \\
37)\end{array}$ \\
\hline $\begin{array}{l}\text { Tu } \\
\text { es } \\
\text { M } \\
\mathbf{R}\end{array}$ & $\begin{array}{c}0.38 \\
* \\
(19.1 \\
2)\end{array}$ & $\begin{array}{c}0.44 \\
* \\
(6.25 \\
)\end{array}$ & $\begin{array}{c}0.60 \\
* \\
(29.3 \\
4)\end{array}$ & $\begin{array}{c}0.55 \\
* \\
(24.2 \\
1)\end{array}$ & $\begin{array}{c}0.29 \\
* \\
(15 . \\
33)\end{array}$ & $\begin{array}{c}0.41 \\
* \\
(20 . \\
03)\end{array}$ & $\begin{array}{c}0.47 \\
* \\
(22 . \\
36)\end{array}$ & $\begin{array}{c}0.36 \\
* \\
(12 \\
95)\end{array}$ & $\begin{array}{c}0.57 \\
* \\
(26.8 \\
0)\end{array}$ & $\begin{array}{c}0.51 \\
* \\
(21.0 \\
4)\end{array}$ & $\begin{array}{c}0.69 \\
* \\
(32 . \\
35)\end{array}$ & $\begin{array}{c}0.64 \\
* \\
(24 . \\
84)\end{array}$ \\
\hline $\begin{array}{c}\mathbf{W e} \\
\mathbf{d} \\
\mathbf{M} \\
\mathbf{R}\end{array}$ & $\begin{array}{c}0.25 \\
* \\
(12.5 \\
6)\end{array}$ & $\begin{array}{c}0.51 \\
* \\
(19.4 \\
8)\end{array}$ & $\begin{array}{c}0.55 \\
* \\
(25.9 \\
0)\end{array}$ & $\begin{array}{c}0.54 \\
* \\
(22.4 \\
6)\end{array}$ & $\begin{array}{c}0.28 \\
* \\
(15 . \\
29)\end{array}$ & $\begin{array}{c}0.54 \\
* \\
(28 . \\
52)\end{array}$ & $\begin{array}{c}0.45 \\
* \\
(20 . \\
40)\end{array}$ & $\begin{array}{c}0.43 \\
* \\
(15 . \\
73)\end{array}$ & $\begin{array}{c}0.51 \\
* \\
(26.5 \\
5)\end{array}$ & $\begin{array}{c}0.52 \\
* \\
(22.1 \\
4)\end{array}$ & $\begin{array}{c}0.61 \\
* \\
(30 . \\
05)\end{array}$ & $\begin{array}{c}0.56 \\
* \\
(20 . \\
62)\end{array}$ \\
\hline $\begin{array}{c}\text { Th } \\
\text { urs } \\
\text { M } \\
\text { R }\end{array}$ & $\begin{array}{c}0.22 \\
* \\
(11.3 \\
4)\end{array}$ & $\begin{array}{c}0.54 \\
* \\
(24.0 \\
8)\end{array}$ & $\begin{array}{c}0.54 \\
* \\
(28.0 \\
2)\end{array}$ & $\begin{array}{c}0.54 \\
* \\
(24.1 \\
5)\end{array}$ & $\begin{array}{c}0.27 \\
* \\
(16 . \\
88)\end{array}$ & $\begin{array}{c}0.39 \\
* \\
(20 . \\
94)\end{array}$ & $\begin{array}{c}0.42 \\
* \\
(23 .\end{array}$ & $\begin{array}{c}0.41 \\
* \\
(16 .\end{array}$ & $\begin{array}{c}0.46 \\
* \\
(22.5 \\
9)\end{array}$ & $\begin{array}{c}0.52 \\
* \\
(22.5 \\
2)\end{array}$ & $\begin{array}{c}0.63 \\
* \\
(31 . \\
68)\end{array}$ & $\begin{array}{c}0.53 \\
* \\
(21 . \\
15)\end{array}$ \\
\hline $\begin{array}{c}\text { Fri } \\
\text { M } \\
\text { R }\end{array}$ & $\begin{array}{c}0.24 \\
* \\
(13.0 \\
2)\end{array}$ & $\begin{array}{c}0.57 \\
* \\
(19.4 \\
0)\end{array}$ & $\begin{array}{c}0.46 \\
* \\
(24.6 \\
4) \\
\end{array}$ & $\begin{array}{c}0.54 \\
* \\
(21.3 \\
1)\end{array}$ & $\begin{array}{c}0.24 \\
* \\
(14 . \\
95)\end{array}$ & $\begin{array}{c}0.28 \\
* \\
(11 . \\
48) \\
\end{array}$ & $\begin{array}{c}0.46 \\
* \\
(22 . \\
81) \\
\end{array}$ & $\begin{array}{c}0.45 \\
* \\
(16 . \\
03) \\
\end{array}$ & $\begin{array}{c}0.45 \\
* \\
(22.4 \\
6)\end{array}$ & $\begin{array}{c}0.56 \\
* \\
(21.9 \\
8) \\
\end{array}$ & $\begin{array}{c}0.63 \\
* \\
(37 . \\
34)\end{array}$ & $\begin{array}{c}0.70 \\
* \\
(27 . \\
61) \\
\end{array}$ \\
\hline
\end{tabular}

*Significant at $1 \%$ level of significance

Table VI: Conditional Market Risk Factor (Model IV)

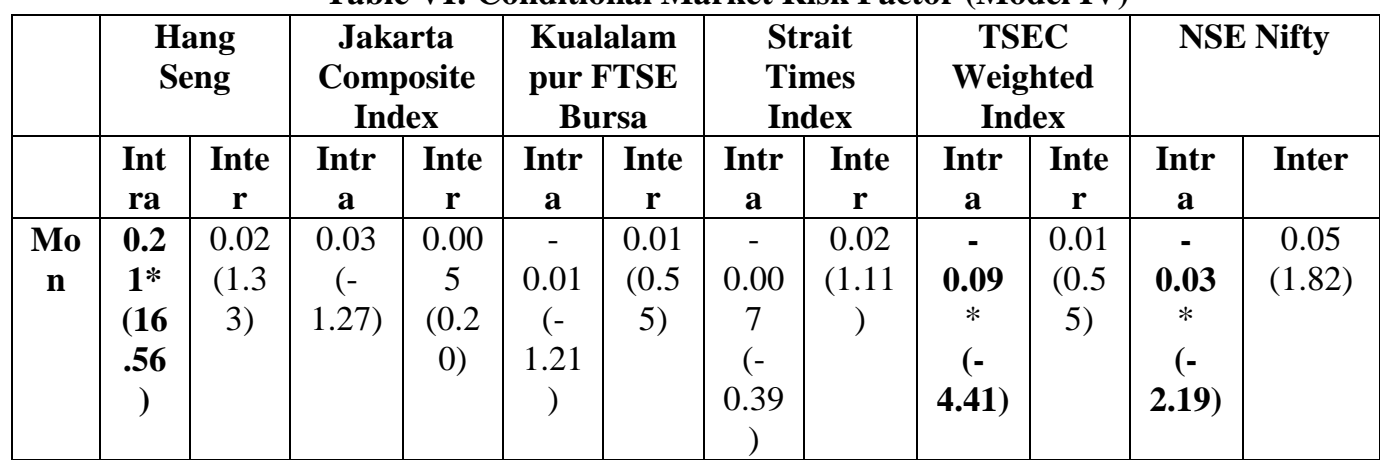




\begin{tabular}{|c|c|c|c|c|c|c|c|c|c|c|c|c|}
\hline $\begin{array}{l}\begin{array}{l}\text { Tu } \\
\text { es }\end{array} \\
\end{array}$ & $\begin{array}{l}0.0 \\
02 \\
(0 . \\
11)\end{array}$ & $\begin{array}{c}0.01 \\
(0.5 \\
6)\end{array}$ & $\begin{array}{c}\mathbf{0 . 0 7} \\
* \\
(2.30 \\
)\end{array}$ & $\begin{array}{c}\mathbf{0 . 0 7} \\
* \\
(\mathbf{2 . 0} \\
\mathbf{9})\end{array}$ & $\begin{array}{c}0.03 \\
(1.6 \\
9)\end{array}$ & $\begin{array}{c}0.00 \\
4 \\
(0.1 \\
7)\end{array}$ & $\begin{array}{c}0.02 \\
(0.9 \\
9)\end{array}$ & $\begin{array}{c}0.02 \\
(0.92 \\
)\end{array}$ & $\begin{array}{c}0.01 \\
(0.58 \\
)\end{array}$ & $\begin{array}{c}- \\
0.01 \\
(- \\
0.40\end{array}$ & $\begin{array}{c}0.04 \\
(1.72 \\
)\end{array}$ & $\begin{array}{c}-0.02 \\
(-0.53)\end{array}$ \\
\hline $\begin{array}{c}\text { We } \\
\text { d }\end{array}$ & $\begin{array}{l}0.0 \\
02 \\
(0 . \\
11) \\
\end{array}$ & $\begin{array}{c}0.00 \\
2 \\
(0.1 \\
1) \\
\end{array}$ & $\begin{array}{c}\mathbf{0 . 1 1} \\
* \\
(3.63 \\
) \\
\end{array}$ & $\begin{array}{c}\mathbf{0 . 1 3} \\
* \\
(3.8 \\
5) \\
\end{array}$ & $\begin{array}{c}0.03 \\
(1.9 \\
0)\end{array}$ & $\begin{array}{c}0.04 \\
(1.6 \\
2)\end{array}$ & $\begin{array}{c}0.02 \\
(0.9 \\
3)\end{array}$ & $\begin{array}{c}0.02 \\
(0.69 \\
)\end{array}$ & $\begin{array}{c}\mathbf{0 . 0 5} \\
* \\
(\mathbf{2 . 0 5} \\
) \\
\end{array}$ & $\begin{array}{c}0.08 \\
* \\
(2.4 \\
5)\end{array}$ & $\begin{array}{c}0.02 \\
(1.01 \\
)\end{array}$ & $\begin{array}{l}0.005 \\
(0.12)\end{array}$ \\
\hline $\begin{array}{l}\text { Th } \\
\text { urs }\end{array}$ & $\begin{array}{c}- \\
0.0 \\
2 \\
(- \\
1.0 \\
9)\end{array}$ & $\begin{array}{c}0.00 \\
8 \\
(0.3 \\
4)\end{array}$ & $\begin{array}{c}0.06 \\
(1.97 \\
)\end{array}$ & $\begin{array}{c}0.07 \\
(1.9 \\
2)\end{array}$ & $\begin{array}{c}\mathbf{0 . 0 4} \\
* \\
(2.1 \\
6)\end{array}$ & $\begin{array}{c}\mathbf{0 . 0 5} \\
* \\
(\mathbf{2 . 0} \\
\mathbf{0})\end{array}$ & $\begin{array}{c}0.00 \\
6 \\
(- \\
0.26 \\
)\end{array}$ & $\begin{array}{c}0.00 \\
1 \\
(0.05 \\
)\end{array}$ & $\begin{array}{c}0.02 \\
(0.63 \\
)\end{array}$ & $\begin{array}{c}0.01 \\
(0.4 \\
6)\end{array}$ & $\begin{array}{c}0.01 \\
(0.65 \\
)\end{array}$ & $\begin{array}{c}-0.02 \\
(-0.65)\end{array}$ \\
\hline Fri & $\begin{array}{c}- \\
0.0 \\
09 \\
(- \\
0.4 \\
7)\end{array}$ & $\begin{array}{c}- \\
0.02 \\
(- \\
0.81 \\
)\end{array}$ & $\begin{array}{c}\mathbf{0 . 1 2} \\
* \\
(3.91 \\
)\end{array}$ & $\begin{array}{c}\text { 0.12 } \\
* \\
(3.5 \\
1)\end{array}$ & $\begin{array}{c}\mathbf{0 . 0 4} \\
* \\
(2.6 \\
1)\end{array}$ & $\begin{array}{c}0.04 \\
(1.6 \\
8)\end{array}$ & $\begin{array}{c}0.04 \\
(1.5 \\
0)\end{array}$ & $\begin{array}{c}0.04 \\
(1.44 \\
)\end{array}$ & $\begin{array}{c}0.05 \\
(1.74 \\
)\end{array}$ & $\begin{array}{c}0.04 \\
(1.4 \\
0)\end{array}$ & $\begin{array}{c}0.02 \\
(0.80 \\
)\end{array}$ & $\begin{array}{c}0.08 \\
(0.20)\end{array}$ \\
\hline $\begin{array}{c}\text { M } \\
\mathbf{R} \\
\text { up }\end{array}$ & $\begin{array}{l}0.1 \\
4 * \\
(8 . \\
41)\end{array}$ & $\begin{array}{c}0.48 \\
* \\
(25 . \\
65)\end{array}$ & $\begin{array}{c}-0.01 \\
(- \\
0.38)\end{array}$ & $\begin{array}{c}- \\
0.24 \\
* \\
(- \\
8.56 \\
)\end{array}$ & $\begin{array}{c}- \\
0.00 \\
7 \\
(- \\
0.37 \\
)\end{array}$ & $\begin{array}{c}- \\
0.10 \\
* \\
(- \\
4.82 \\
)\end{array}$ & $\begin{array}{c}0.09 \\
* \\
(- \\
3.26 \\
)\end{array}$ & $\begin{array}{c}- \\
0.31 \\
* \\
(- \\
13.6 \\
2)\end{array}$ & $\begin{array}{c}-0.02 \\
(- \\
0.84)\end{array}$ & $\begin{array}{c}- \\
0.24 \\
* \\
(- \\
9.01 \\
)\end{array}$ & $\begin{array}{c}0.73 \\
* \\
(46.7 \\
5)\end{array}$ & $\begin{array}{l}-0.29 * \\
(-9.88)\end{array}$ \\
\hline $\begin{array}{c}\text { M } \\
\mathbf{R} \\
\text { do } \\
\mathbf{w n}\end{array}$ & $\begin{array}{c}- \\
0.2 \\
6 * \\
(- \\
15 . \\
73)\end{array}$ & $\begin{array}{c}0.57 \\
* \\
(32 . \\
93)\end{array}$ & $\begin{array}{c}0.00 \\
7 \\
(0.26 \\
)\end{array}$ & $\begin{array}{c}- \\
0.00 \\
4 \\
(- \\
0.14 \\
) \\
\end{array}$ & $\begin{array}{c}0.03 \\
(1.8 \\
9)\end{array}$ & $\begin{array}{c}0.02 \\
* \\
(0.8 \\
6)\end{array}$ & $\begin{array}{c}0.03 \\
(1.5 \\
9)\end{array}$ & $\begin{array}{c}- \\
0.15 \\
* \\
(- \\
6.26)\end{array}$ & $\begin{array}{c}- \\
0.05 \\
* \\
(- \\
2.14)\end{array}$ & $\begin{array}{c}- \\
0.08 \\
* \\
(- \\
2.73 \\
)\end{array}$ & $\begin{array}{c}0.61 \\
* \\
(45.4 \\
7)\end{array}$ & $\begin{array}{l}-0.20^{*} \\
(-6.30)\end{array}$ \\
\hline
\end{tabular}

*Significant at $1 \%$ level of significance

Table VII: Conditional Market Risk Factor across the Days of the Week (Model V)

\begin{tabular}{|c|c|c|c|c|c|c|c|c|c|c|c|c|}
\hline & \multicolumn{2}{|c|}{$\begin{array}{l}\text { Hang } \\
\text { Seng }\end{array}$} & \multicolumn{2}{|c|}{$\begin{array}{l}\text { Jakarta } \\
\text { Composit } \\
\text { e Index }\end{array}$} & \multicolumn{2}{|c|}{$\begin{array}{c}\text { Kualalamp } \\
\text { ur FTSE } \\
\text { Bursa }\end{array}$} & \multicolumn{2}{|c|}{$\begin{array}{l}\text { Strait } \\
\text { Times } \\
\text { Index }\end{array}$} & \multicolumn{2}{|c|}{$\begin{array}{c}\text { TSEC } \\
\text { Weighted } \\
\text { Index }\end{array}$} & \multicolumn{2}{|c|}{ NSE Nifty } \\
\hline & $\begin{array}{c}\text { Int } \\
\text { ra }\end{array}$ & $\begin{array}{c}\text { Int } \\
\text { er }\end{array}$ & $\begin{array}{c}\text { Int } \\
\text { ra }\end{array}$ & $\begin{array}{c}\text { Int } \\
\text { er }\end{array}$ & $\begin{array}{c}\text { Intr } \\
\mathbf{a}\end{array}$ & $\begin{array}{c}\text { Inte } \\
\mathbf{r}\end{array}$ & $\begin{array}{l}\text { Int } \\
\text { ra }\end{array}$ & $\begin{array}{l}\text { Int } \\
\text { er }\end{array}$ & $\begin{array}{c}\text { Int } \\
\text { ra }\end{array}$ & $\begin{array}{c}\text { Inte } \\
\mathbf{r}\end{array}$ & $\begin{array}{c}\text { Intr } \\
\mathbf{a}\end{array}$ & $\begin{array}{c}\text { Inte } \\
\mathbf{r}\end{array}$ \\
\hline $\begin{array}{c}\text { Mo } \\
\text { n }\end{array}$ & $\begin{array}{c}\mathbf{0 . 2} \\
\mathbf{0}^{*} \\
(13 . \\
09)\end{array}$ & $\begin{array}{c}0.0 \\
1 \\
(0.4 \\
3)\end{array}$ & $\begin{array}{c}- \\
0.0 \\
2 \\
(- \\
0.8 \\
7)\end{array}$ & $\begin{array}{c}- \\
0.0 \\
3 \\
(- \\
0.9 \\
1)\end{array}$ & $\begin{array}{c}- \\
0.00 \\
9 \\
(- \\
0.06 \\
)\end{array}$ & $\begin{array}{c}0.01 \\
(0.4 \\
0)\end{array}$ & $\begin{array}{c}- \\
0.0 \\
2 \\
(- \\
0.8 \\
7)\end{array}$ & $\begin{array}{c}0.0 \\
2 \\
(0.9 \\
4)\end{array}$ & $\begin{array}{c}- \\
0.0 \\
8^{*} \\
(- \\
3.2 \\
5)\end{array}$ & $\begin{array}{l}0.03 \\
(1.1 \\
5)\end{array}$ & $\begin{array}{c}- \\
0.03 \\
(- \\
1.72 \\
)\end{array}$ & $\begin{array}{c}0.0 \\
2 \\
(0.5 \\
5)\end{array}$ \\
\hline $\begin{array}{c}\text { Tue } \\
\text { s }\end{array}$ & $\begin{array}{c}0.0 \\
2 \\
(1.0 \\
8)\end{array}$ & $\begin{array}{c}0.0 \\
04 \\
(0.1 \\
3)\end{array}$ & $\begin{array}{c}0.0 \\
8 \\
(1.9 \\
7)\end{array}$ & $\begin{array}{c}0.1 \\
3^{*} \\
(2.8 \\
3)\end{array}$ & $\begin{array}{c}0.00 \\
9 \\
(0.4 \\
3)\end{array}$ & $\begin{array}{c}0.01 \\
(0.3 \\
8)\end{array}$ & $\begin{array}{c}0.0 \\
3 \\
(0.9 \\
7)\end{array}$ & $\begin{array}{c}- \\
0.0 \\
04 \\
(- \\
0.1 \\
2)\end{array}$ & $\begin{array}{c}0.0 \\
08 \\
(0.2 \\
4)\end{array}$ & $\begin{array}{c}- \\
0.05 \\
(- \\
1.10 \\
)\end{array}$ & $\begin{array}{c}0.05 \\
(1.6 \\
5)\end{array}$ & $\begin{array}{c}0.0 \\
06 \\
(0.1 \\
3)\end{array}$ \\
\hline $\begin{array}{c}\text { We } \\
\text { d }\end{array}$ & $\begin{array}{c}0.0 \\
3 \\
(1.4 \\
0)\end{array}$ & $\begin{array}{c}0.0 \\
4 \\
(1.2 \\
8)\end{array}$ & $\begin{array}{c}\mathbf{0 . 1} \\
\mathbf{0}^{*} \\
(2.6 \\
7)\end{array}$ & $\begin{array}{c}0.1 \\
1 * \\
(2.4 \\
7)\end{array}$ & $\begin{array}{c}0.03 \\
(1.3 \\
1)\end{array}$ & $\begin{array}{l}0.04 \\
(1.3 \\
6)\end{array}$ & $\begin{array}{c}0.0 \\
1 \\
(0.3 \\
7)\end{array}$ & $\begin{array}{c}0.0 \\
3 \\
(1.0 \\
0)\end{array}$ & $\begin{array}{c}0.0 \\
4 \\
(1.2 \\
7)\end{array}$ & $\begin{array}{c}0.02 \\
(0.5 \\
4)\end{array}$ & $\begin{array}{c}- \\
0.01 \\
(- \\
0.51 \\
)\end{array}$ & $\begin{array}{c}0.0 \\
3^{*} \\
(0.6 \\
6)\end{array}$ \\
\hline
\end{tabular}




\begin{tabular}{|c|c|c|c|c|c|c|c|c|c|c|c|c|}
\hline $\begin{array}{l}\text { Thu } \\
\text { rs }\end{array}$ & $\begin{array}{c}0.0 \\
06 \\
(- \\
0.2 \\
9)\end{array}$ & $\begin{array}{c}0.0 \\
5 \\
(1.4 \\
7)\end{array}$ & $\begin{array}{c}0.0 \\
5 \\
(1.2 \\
2)\end{array}$ & $\begin{array}{c}0.1 \\
6^{*} \\
(3.3 \\
9)\end{array}$ & $\begin{array}{c}0.01 \\
(0.5 \\
4)\end{array}$ & $\begin{array}{c}0.05 \\
(1.4 \\
4)\end{array}$ & $\begin{array}{c}0.0 \\
2 \\
(0.7 \\
9)\end{array}$ & $\begin{array}{c}0.0 \\
1 \\
(0.4 \\
1)\end{array}$ & $\begin{array}{c}0.0 \\
04 \\
(1.2 \\
7)\end{array}$ & $\begin{array}{c}0.04 \\
(0.8 \\
4)\end{array}$ & $\begin{array}{c}0.05 \\
(1.7 \\
4)\end{array}$ & $\begin{array}{c}0.0 \\
3 \\
(0.5 \\
6)\end{array}$ \\
\hline Fri & $\begin{array}{c}- \\
0.0 \\
01 \\
(- \\
0.0 \\
6)\end{array}$ & $\begin{array}{c}- \\
0.0 \\
2 \\
(- \\
0.6 \\
6)\end{array}$ & $\begin{array}{c}0.1 \\
1^{*} \\
(2.9 \\
3)\end{array}$ & $\begin{array}{c}\mathbf{0 . 1}^{2} \\
7^{*} \\
(3.6 \\
\mathbf{0})\end{array}$ & $\begin{array}{c}0.02 \\
(1.2 \\
7)\end{array}$ & $\begin{array}{c}0.04 \\
(1.0 \\
4)\end{array}$ & $\begin{array}{c}0.0 \\
4 \\
(1.5 \\
2)\end{array}$ & $\begin{array}{c}0.0 \\
3 \\
(0.8 \\
7)\end{array}$ & $\begin{array}{c}0.0 \\
04 \\
(0.1 \\
1)\end{array}$ & $\begin{array}{c}- \\
0.00 \\
2 \\
(- \\
0.05 \\
)\end{array}$ & $\begin{array}{c}0.01 \\
(0.3 \\
8)\end{array}$ & $\begin{array}{c}0.0 \\
5 \\
(0.9 \\
8)\end{array}$ \\
\hline $\begin{array}{c}\text { Mo } \\
\text { n } \\
\text { up }\end{array}$ & $\begin{array}{c}0.1 \\
8^{*} \\
(4.5 \\
5)\end{array}$ & $\begin{array}{c}0.5 \\
6 \\
(15 . \\
22)\end{array}$ & $\begin{array}{c}0.0 \\
2 \\
(- \\
0.4 \\
0)\end{array}$ & $\begin{array}{c}0.2 \\
1^{*} \\
(- \\
3.9 \\
6)\end{array}$ & $\begin{array}{c}0.05 \\
(- \\
1.17 \\
)\end{array}$ & $\begin{array}{c}0.13 \\
(- \\
2.92 \\
)\end{array}$ & $\begin{array}{c}0.0 \\
5 \\
(- \\
0.9 \\
3)\end{array}$ & $\begin{array}{c}0.3 \\
6^{*} \\
(- \\
7.6 \\
0)\end{array}$ & $\begin{array}{c}0.0 \\
3 \\
(0.8 \\
4)\end{array}$ & $\begin{array}{c}0.38 \\
* \\
(- \\
7.05 \\
)\end{array}$ & $\begin{array}{c}0.80 \\
* \\
(25 . \\
63)\end{array}$ & $\begin{array}{c}0.3 \\
6^{*} \\
(- \\
6.2 \\
5)\end{array}$ \\
\hline $\begin{array}{c}\text { Mo } \\
\text { n } \\
\text { dow } \\
\text { n }\end{array}$ & $\begin{array}{c}0.3 \\
7 * \\
(8.5 \\
9)\end{array}$ & $\begin{array}{c}0.5 \\
7^{*} \\
(13 . \\
04)\end{array}$ & $\begin{array}{c}0.0 \\
2 \\
(0.3 \\
8)\end{array}$ & $\begin{array}{c}0.1 \\
6^{*} \\
(- \\
2.3 \\
5)\end{array}$ & $\begin{array}{c}0.10 \\
* \\
(2.2 \\
6)\end{array}$ & $\begin{array}{c}0.01 \\
(- \\
0.24 \\
)\end{array}$ & $\begin{array}{c}0.0 \\
09 \\
(- \\
0.1 \\
6)\end{array}$ & $\begin{array}{c}0.2 \\
1^{*} \\
(- \\
3.7 \\
5)\end{array}$ & $\begin{array}{c}- \\
0.0 \\
7 \\
(- \\
1.1 \\
0)\end{array}$ & $\begin{array}{c}- \\
0.12 \\
* \\
(- \\
2.02 \\
)\end{array}$ & $\begin{array}{c}0.80 \\
* \\
(24 . \\
89)\end{array}$ & $\begin{array}{c}0.4 \\
4^{*} \\
(- \\
6.3 \\
2)\end{array}$ \\
\hline $\begin{array}{l}\text { Tue } \\
\text { s up }\end{array}$ & $\begin{array}{c}0.1 \\
1^{*} \\
(2.8 \\
2)\end{array}$ & $\begin{array}{c}0.5 \\
0^{*} \\
(11 . \\
28)\end{array}$ & $\begin{array}{c}0.0 \\
7 \\
(- \\
0.8 \\
7)\end{array}$ & $\begin{array}{c}- \\
0.2 \\
1^{*} \\
(- \\
3.3 \\
9)\end{array}$ & $\begin{array}{c}0.00 \\
9 \\
(0.1 \\
8)\end{array}$ & $\begin{array}{c}- \\
0.11 \\
(- \\
1.93 \\
)\end{array}$ & $\begin{array}{c}- \\
0.1 \\
0 \\
(- \\
1.6 \\
8)\end{array}$ & $\begin{array}{c}- \\
0.2 \\
1 * \\
(- \\
4.1 \\
3)\end{array}$ & $\begin{array}{c}- \\
0.0 \\
4 \\
(- \\
0.6 \\
1)\end{array}$ & $\begin{array}{c}- \\
0.20 \\
* \\
(- \\
3.11 \\
)\end{array}$ & $\begin{array}{c}0.73 \\
* \\
(19 . \\
19)\end{array}$ & $\begin{array}{c}- \\
0.1 \\
8^{*} \\
(- \\
2.3 \\
8)\end{array}$ \\
\hline $\begin{array}{c}\text { Tue } \\
\text { s } \\
\text { dow } \\
\text { n }\end{array}$ & $\begin{array}{c}- \\
0.2 \\
5 * \\
(- \\
6.0 \\
4)\end{array}$ & $\begin{array}{c}0.4 \\
9 * \\
(14 . \\
39)\end{array}$ & $\begin{array}{c}0.0 \\
3 \\
(0.5 \\
1)\end{array}$ & $\begin{array}{c}0.1 \\
2 \\
(1.8 \\
6)\end{array}$ & $\begin{array}{c}0.01 \\
(0.2 \\
9)\end{array}$ & $\begin{array}{c}0.05 \\
(1.0 \\
9)\end{array}$ & $\begin{array}{c}- \\
0.2 \\
9 \\
(- \\
1.7 \\
2)\end{array}$ & $\begin{array}{c}- \\
0.2 \\
0 * \\
(- \\
3.8 \\
3)\end{array}$ & $\begin{array}{c}- \\
0.1 \\
3 \\
(- \\
1.9 \\
4)\end{array}$ & $\begin{array}{c}- \\
0.11 \\
(- \\
1.67 \\
)\end{array}$ & $\begin{array}{c}0.66 \\
* \\
(18 . \\
26)\end{array}$ & $\begin{array}{c}- \\
0.1 \\
3 \\
(- \\
1.8 \\
9)\end{array}$ \\
\hline $\begin{array}{c}\text { We } \\
\text { d } \\
\text { up }\end{array}$ & $\begin{array}{c}0.1 \\
1 * \\
(2.6 \\
9)\end{array}$ & $\begin{array}{c}0.4 \\
2 * \\
(10 . \\
51)\end{array}$ & $\begin{array}{c}0.1 \\
1 \\
(- \\
1.6 \\
6)\end{array}$ & $\begin{array}{c}- \\
0.1 \\
8^{*} \\
(- \\
3.0 \\
1)\end{array}$ & $\begin{array}{c}0.13 \\
* \\
(- \\
3.01 \\
)\end{array}$ & $\begin{array}{c}- \\
0.17 \\
* \\
(- \\
3.63 \\
)\end{array}$ & $\begin{array}{c}- \\
0.1 \\
4 * \\
(- \\
2.2 \\
3)\end{array}$ & $\begin{array}{c}- \\
0.3 \\
8 * \\
(- \\
7.5 \\
2)\end{array}$ & $\begin{array}{c}- \\
0.1 \\
3 * \\
(- \\
2.1 \\
6)\end{array}$ & $\begin{array}{c}- \\
0.08 \\
(- \\
1.42 \\
)\end{array}$ & $\begin{array}{c}0.74 \\
* \\
(20 . \\
35)\end{array}$ & $\begin{array}{c}- \\
0.2 \\
5^{*} \\
(- \\
3.9 \\
5)\end{array}$ \\
\hline $\begin{array}{c}\text { We } \\
\text { d } \\
\text { dow } \\
\text { n }\end{array}$ & $\begin{array}{c}- \\
0.2 \\
0 * \\
(- \\
5.3 \\
1)\end{array}$ & $\begin{array}{c}0.6 \\
1 * \\
(13 . \\
67)\end{array}$ & $\begin{array}{c}0.1 \\
0 \\
(- \\
1.9 \\
4)\end{array}$ & $\begin{array}{c}0.2 \\
2^{*} \\
(- \\
2.9 \\
9)\end{array}$ & $\begin{array}{c}0.02 \\
(- \\
0.56 \\
)\end{array}$ & $\begin{array}{c}0.03 \\
(- \\
0.60 \\
)\end{array}$ & $\begin{array}{c}0.1 \\
5^{*} \\
(- \\
2.8 \\
4)\end{array}$ & $\begin{array}{c}0.1 \\
3 * \\
(- \\
2.2 \\
9)\end{array}$ & $\begin{array}{c}0.0 \\
7 \\
(1.0 \\
1)\end{array}$ & $\begin{array}{c}0.09 \\
(- \\
1.28 \\
)\end{array}$ & $\begin{array}{c}0.49 \\
* \\
(15 . \\
28)\end{array}$ & $\begin{array}{c}0.1 \\
8^{*} \\
(- \\
2.1 \\
6)\end{array}$ \\
\hline $\begin{array}{c}\text { Thu } \\
\text { rs } \\
\text { up }\end{array}$ & $\begin{array}{c}0.1 \\
5^{*} \\
(4.2 \\
9)\end{array}$ & $\begin{array}{c}0.4 \\
4^{*} \\
(10 . \\
52)\end{array}$ & $\begin{array}{c}0.0 \\
5 \\
(0.7 \\
8)\end{array}$ & $\begin{array}{c}0.3 \\
5^{*} \\
(- \\
5.4 \\
1)\end{array}$ & $\begin{array}{c}0.10 \\
* \\
(2.5 \\
7)\end{array}$ & $\begin{array}{c}0.02 \\
(- \\
0.43 \\
)\end{array}$ & $\begin{array}{c}0.0 \\
6 \\
(- \\
1.1 \\
3)\end{array}$ & $\begin{array}{c}0.3 \\
0^{*} \\
(- \\
6.3 \\
6)\end{array}$ & $\begin{array}{c}0.0 \\
2 \\
(0.3 \\
7)\end{array}$ & $\begin{array}{c}0.30 \\
* \\
(- \\
5.40 \\
)\end{array}$ & $\begin{array}{c}0.61 \\
* \\
(15 . \\
98)\end{array}$ & $\begin{array}{c}0.2 \\
5^{*} \\
(- \\
3.7 \\
8)\end{array}$ \\
\hline $\begin{array}{c}\text { Thu } \\
\text { rs } \\
\text { dow } \\
\text { n }\end{array}$ & $\begin{array}{c}- \\
0.2 \\
6^{*} \\
(- \\
7.3\end{array}$ & $\begin{array}{c}0.6 \\
1 * \\
(19 . \\
70)\end{array}$ & $\begin{array}{c}0.0 \\
2 \\
(0.3 \\
0)\end{array}$ & $\begin{array}{c}0.1 \\
5^{*} \\
(2.1 \\
9)\end{array}$ & $\begin{array}{c}0.06 \\
(1.6 \\
7)\end{array}$ & $\begin{array}{c}(1.6 \\
6)\end{array}$ & $\begin{array}{c}0.1 \\
6^{*} \\
(3.8 \\
3)\end{array}$ & $\begin{array}{c}- \\
0.0 \\
9 \\
(- \\
1.7\end{array}$ & $\begin{array}{c}- \\
0.0 \\
1 \\
(- \\
0.1\end{array}$ & $\begin{array}{c}0.05 \\
(0.8 \\
8)\end{array}$ & $\begin{array}{c}0.65 \\
* \\
(20 . \\
57)\end{array}$ & $\begin{array}{c}- \\
0.0 \\
7 \\
(- \\
1.2\end{array}$ \\
\hline
\end{tabular}


Day-of-the-Week Effect on Stock Market Return and Volatility: Evidence from Indian Stock Market

\begin{tabular}{|c|c|c|c|c|c|c|c|c|c|c|c|c|}
\hline & $1)$ & & & & & & & $3)$ & $6)$ & & & $6)$ \\
\hline Fri & 0.2 & 0.5 & 0.0 & - & 0.01 & - & - & - & - & - & 0.71 & - \\
up & $0^{*}$ & $6^{*}$ & 8 & 0.2 & $(0.2$ & 0.10 & 0.0 & 0.2 & 0.0 & 0.19 & $*$ & 0.3 \\
& $(5.1$ & $(10$. & $(1.1$ & $3^{*}$ & $9)$ & $(-$ & 5 & $6^{*}$ & 6 & $*$ & $(22$. & $5^{*}$ \\
& $4)$ & $84)$ & $8)$ & $(-$ & & 1.72 & $(-$ & $(-$ & $(-$ & $(-$ & $92)$ & $(-$ \\
& & & & 3.2 & & ) & 0.8 & 4.5 & 1.1 & 2.65 & & 5.0 \\
& & & & $7)$ & & & $5)$ & $7)$ & $1)$ & ) & & $6)$ \\
\hline Fri & - & 0.5 & 0.0 & 0.0 & 0.02 & - & 0.0 & - & 0.0 & - & 0.58 & - \\
dow & 0.2 & $7 *$ & 7 & 4 & $(0.8$ & 0.01 & 5 & 0.1 & 2 & 0.18 & $*$ & 0.2 \\
n & $4^{*}$ & $(12$. & $(1.4$ & $(0.6$ & $7)$ & $(-$ & $(1.0$ & $5^{*}$ & $(0.3$ & $*$ & $(22$. & $2^{*}$ \\
& $(-$ & $16)$ & $7)$ & $5)$ & & 0.28 & $6)$ & $(-$ & $0)$ & $(-$ & $75)$ & $(-$ \\
& 8.0 & & & & & ) & & 2.5 & & 2.43 & & 2.9 \\
& $7)$ & & & & & & & $7)$ & & ) & & $5)$ \\
\hline
\end{tabular}

*Significant at $1 \%$ level of significance 